Article

\title{
Ground Ammonia Concentrations over China Derived from Satellite and Atmospheric Transport Modeling
}

\author{
Lei Liu ${ }^{1}$, Xiuying Zhang ${ }^{1, *}$, Wen $\mathrm{Xu}^{2}{ }^{2}$, Xuejun Liu ${ }^{2}$, Xuehe Lu ${ }^{1}$, Shanqian Wang ${ }^{1}$, \\ Wuting Zhang ${ }^{1}$ and Limin Zhao ${ }^{1,3}$ \\ 1 Jiangsu Provincial Key Laboratory of Geographic Information Science and Technology, \\ International Institute for Earth System Science, Nanjing University, Nanjing 210023, China; \\ liulei_nju_geo@163.com (L.L.); luxh43@gmail.com (X.L.); shanqianwang@163.com (S.W.); \\ zhangwuting75@163.com (W.Z.); zlm2016nju@163.com (L.Z.) \\ 2 College of Resources and Environmental Sciences, Centre for Resources, Environment and Food Security, \\ Key Lab of Plant-Soil Interactions of MOE, China Agricultural University, Beijing 100193, China; \\ hi.xuwen@163.com (W.X.); liu310@cau.edu.cn (X.L.) \\ 3 Jiangsu Center for Collaborative Innovation in Geographical Information Resource Development and \\ Application, Nanjing 210023, China \\ * Correspondence: lzhxy77@163.com
}

Academic Editors: Yang Liu, Jun Wang, Omar Torres, Richard Müller and Prasad S. Thenkabail Received: 27 March 2017; Accepted: 7 May 2017; Published: 15 May 2017

\begin{abstract}
As a primary basic gas in the atmosphere, atmospheric ammonia $\left(\mathrm{NH}_{3}\right)$ plays an important role in determining air quality, environmental degradation, and climate change. However, the limited ground observation currently presents a barrier to estimating ground $\mathrm{NH}_{3}$ concentrations on a regional scale, thus preventing a full understanding of the atmospheric processes in which this trace gas is involved. This study estimated the ground $\mathrm{NH}_{3}$ concentrations over China, combining the Infrared Atmospheric Sounding Interferometer (IASI) satellite $\mathrm{NH}_{3}$ columns and $\mathrm{NH}_{3}$ profiles from an atmospheric chemistry transport model (CTM). The estimated ground $\mathrm{NH}_{3}$ concentrations showed agreement with the variability in annual ground $\mathrm{NH}_{3}$ measurements from the Chinese Nationwide Nitrogen Deposition Monitoring Network (NNDMN). Great spatial heterogeneity of ground $\mathrm{NH}_{3}$ concentrations was found across China, and high ground $\mathrm{NH}_{3}$ concentrations were found in Northern China, Southeastern China, and some areas in Xinjiang Province. The maximum ground $\mathrm{NH}_{3}$ concentrations over China occurred in summer, followed by spring, autumn, and winter seasons, which were in agreement with the seasonal patterns of $\mathrm{NH}_{3}$ emissions in China. This study suggested that a combination of $\mathrm{NH}_{3}$ profiles from CTMs and $\mathrm{NH}_{3}$ columns from satellite obtained reliable ground $\mathrm{NH}_{3}$ concentrations over China.
\end{abstract}

Keywords: $\mathrm{NH}_{3}$; satellite; CTM; spatial; ground

\section{Introduction}

Ammonia $\left(\mathrm{NH}_{3}\right)$ is the primary form of reactive nitrogen $(\mathrm{Nr})$ in the environment and a key component of the ecosystems, representing more than half of atmospheric Nr emissions [1,2]. $\mathrm{NH}_{3}$ emissions have been increasing in recent years due to the increasing agricultural livestock numbers and the increasing application of $\mathrm{Nr}$ fertilization [2,3], resulting in the high $\mathrm{NH}_{3}$ concentrations in the atmosphere. $\mathrm{NH}_{3}$ increase has enhanced the acidification and eutrophication of the ecosystems on local and international scales [2,4]. Previous studies have shown that the lifetime of $\mathrm{NH}_{3}$ is very short from hours to several days [5,6] converting to particulate matter (PM) as well as leading to dry and wet depositions. $\mathrm{NH}_{3}$ reacts with acid-forming compounds such as sulfur 
dioxide $\left(\mathrm{SO}_{2}\right)$ and nitrogen oxides $\left(\mathrm{NO}_{\mathrm{x}}\right)$ to form particles containing ammonium sulfate $\left(\left(\mathrm{NH}_{4}\right)_{2} \mathrm{SO}_{4}\right)$ and ammonium nitrate $\left(\mathrm{NH}_{4} \mathrm{NO}_{3}\right)$ in the atmosphere [7]. These processes increase the amount of atmospheric particulate matter, particularly for particles smaller than 2.5 micrometers in diameter (PM2.5), thereby reducing visibility and negatively affecting environmental and human health [8,9]. Therefore, monitoring the ground $\mathrm{NH}_{3}$ concentrations on a regional scale is vitally important to assist in enacting effective measures to protect the eco-environments and public health, with respect to air, soil, and water quality.

Progress in the understanding of the $\mathrm{NH}_{3}$ cycling process, flux measurements, and instrumentation have allowed advances in estimating $\mathrm{NH}_{3}$ concentrations in the atmosphere on a local or regional scale, based on the simulation of the chemical transport models (CTM). For example, a coupled MM5-CMAQ modeling system was used for computing the ground $\mathrm{NH}_{3}$ concentration based on the $\mathrm{NH}_{3}$ emission developed with a spatial resolution of $27 \mathrm{~km} \times 27 \mathrm{~km}$ in the Beijing-Tianjin-Hebei (BTH) region of China [10]. The simulation error of ground $\mathrm{NH}_{3}$ concentration in different seasons in BTH range from $-24.4 \%$ to $7.8 \%$, indicating the ground $\mathrm{NH}_{3}$ concentrations simulated by MM5-CMAQ are comparable with the observations; A GEOS-Chem model was used to estimate the global and seasonal $\mathrm{NH}_{3}$ with a resolution of $2^{\circ}$ latitude $\times 2.5^{\circ}$ longitude [11], showing that the simulated ground $\mathrm{NH}_{3}$ concentrations are biased low compared to the Tropospheric Emission Spectrometer (TES) with seasonal mean differences of -0.92 to $1.58 \mathrm{ppb}$. Similar reports on estimating ground $\mathrm{NH}_{3}$ concentrations from CMT could also be tracked in several studies [12-14]. Although these CTMs could simulate the profiles of $\mathrm{NH}_{3}$ concentrations in the atmosphere, the ground $\mathrm{NH}_{3}$ concentrations over a large scale, such as on a national scale over the entire area of China, are still poorly understood due to the large pixel sizes and the relatively high uncertainties resulting from errors of the emission data and the simplification of the chemistry schemes. Fortunately, numerous studies have shown that CTMs can produce profiles for aerosol [15-18], $\mathrm{NO}_{2}$ [19-21], $\mathrm{NH}_{3}[2,22-24]$, and $\mathrm{SO}_{2}[19,25]$, denoting that the vertical profiles of the $\mathrm{NH}_{3}$ concentrations from CTM were highly beneficial in calculating the ground $\mathrm{NH}_{3}$ concentrations.

In comparison with CTM simulations, satellite remote sensing is considered as an observational perspective and offers another way to obtain large-scale $\mathrm{NH}_{3}$ columns with high spatial resolutions, based on advanced infrared spectroscopy (IR) sounders, such as the Infrared Atmospheric Sounding Interferometer (IASI), the Tropospheric Emission Spectrometer (TES), and the Cross-track Infrared Sounder (CrIS) [26,27]. Large-scale distributions of IASI $\mathrm{NH}_{3}$ columns could denote the status of $\mathrm{NH}_{3}$ levels in regions not covered by ground measurement networks, expanding insight into new $\mathrm{NH}_{3}$ sources including industry, agriculture, and biomass burning [2,22]. However, satellite $\mathrm{NH}_{3}$ can only provide the columns and has no information of the vertical distributions of the columns (from the ground to the top of the atmosphere), presenting a barrier in obtaining the ground $\mathrm{NH}_{3}$ concentrations. Fortunately, as mentioned in the last paragraph, the detailed $\mathrm{NH}_{3}$ profiles could be obtained from CTMs. Combining the advantages of CTMs ( $\mathrm{NH}_{3}$ profiles) and satellite observations (large-scale overages with high spatiotemporal resolutions), the ground $\mathrm{NH}_{3}$ concentrations can be derived.

We aimed to generate spatiotemporal ground $\mathrm{NH}_{3}$ concentrations with the aid of the remotely sensed $\mathrm{NH}_{3}$ columns and vertical $\mathrm{NH}_{3}$ profiles from a CTM. The estimated ground $\mathrm{NH}_{3}$ concentrations were further compared with the national ground monitoring network of the Chinese Nationwide Nitrogen Deposition Monitoring Network (NNDMN). Our purpose is not to replace traditional algorithms, but to combine the advantages of satellite with high spatial and temporal resolutions, and CTMs with detailed $\mathrm{NH}_{3}$ vertical profiles in order to obtain high spatiotemporal ground $\mathrm{NH}_{3}$ concentrations over China, hence providing basic information for the ground status of $\mathrm{NH}_{3}$ concentrations and guiding the monitoring plans in the future over China. 


\section{Materials and Methods}

\subsection{Ground $\mathrm{NH}_{3}$ Concentrations in the Atmosphere}

Monitoring ground-based $\mathrm{NH}_{3}$ concentrations on a regional scale is not straightforward due to the technical limitations and great variability of the concentrations in time and space [28]. While the availability of $\mathrm{NH}_{3}$ concentration data and the flux measurements on local scales is increasing, the measurements on a regional scale are sparser [1].

We used the monthly ground $\mathrm{NH}_{3}$ concentrations from the Chinese Nationwide Nitrogen Deposition Monitoring Network (NNDMN, made available on request by Prof. X.J. Liu, China Agricultural University) to evaluate the accuracy of the satellite-derived ground $\mathrm{NH}_{3}$ concentrations. Monthly $\mathrm{NH}_{3}$ concentrations (in units of $\mu \mathrm{g} \mathrm{N} \mathrm{m}{ }^{-3}$ ) were measured at 44 sites from 2010 to 2013 (Figure 1). The network mainly covered farmland sites but also included some grassland (two) and forest (four) sites across China $[29,30]$. The ground $\mathrm{NH}_{3}$ concentrations in NNDMN were monitored using both DEnuder for Long-Term Atmospheric (DELTA) systems as well as Adapted Low-cost, Passive High Absorption (ALPHA) samplers [30,31]. ALPHA is a passive sampling system, while DELTA is an active sampling system. Monthly ground $\mathrm{NH}_{3}$ concentrations were mostly monitored by DELTA, and few monitoring sites were measured by ALPHA. Xu et al. [30] showed that these two methods on measuring ground $\mathrm{NH}_{3}$ concentrations were not significantly different and can be considered consistent.

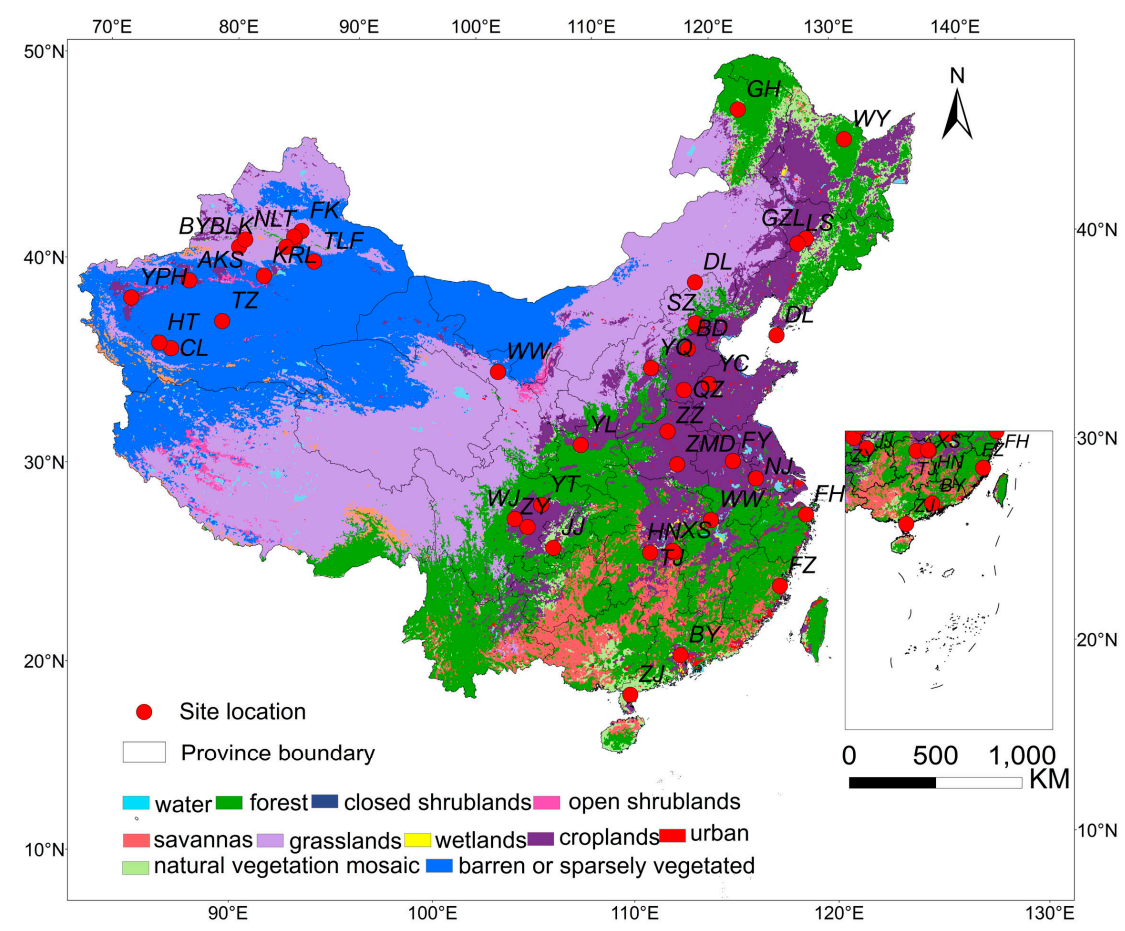

Figure 1. Spatial distribution of ground monitoring $\mathrm{NH}_{3}$ sites in the Chinese Nationwide Nitrogen Deposition Monitoring Network (NNDMN).

\section{2. $\mathrm{IASI} \mathrm{NH}_{3}$ Columns}

The IASI instrument is on board the polar sun-synchronous MetOp platform, which crosses the equator at a mean local solar time of 9.30 a.m. and p.m. [32]. In this study, we used the measurements from the morning overpass as they are generally more sensitive to $\mathrm{NH}_{3}$ because of higher thermal contrast at this time of day [1]. IASI has an elliptical footprint of $12 \mathrm{~km}$ by $12 \mathrm{~km}$ (at nadir) and up to $20 \mathrm{~km}$ by $39 \mathrm{~km}$ (off nadir), depending on the satellite viewing angle. The availability of measurements is mainly dependent on the cloud coverage. 
The current method is based on the calculation of a spectral hyperspectral range index and subsequent conversion to a $\mathrm{NH}_{3}$ total column using a neural network. Details on the retrieval algorithms can be found in Whitburn et al. [32]. We requested the IASI $\mathrm{NH}_{3}$ data from Université Libre De Bruxelles, and processed the daily observation data to monthly average data for deriving the ground $\mathrm{NH}_{3}$. In the present work, the observations with a cloud coverage lower than $25 \%$, and relative error lower than $100 \%$ or absolute error less than $5 \times 15$ molec. $\mathrm{cm}^{-2}$ were processed [27].

\section{3. $\mathrm{NH}_{3}$ Profiles from MOZART-4}

MOZART-4 (Model for Ozone and Related chemical Tracers, version 4) is a three-dimensional (3-D) global chemical transport model simulating the chemical and transport processes, which can be driven by essentially any meteorological dataset and with any emissions inventory $[24,33]$. The MOZART-4 used in this study includes detailed chemistry, an improved scheme for the determination of albedo, aerosols, online calculations of photolysis rates, dry deposition, $\mathrm{H}_{2} \mathrm{O}$ concentration, and biogenic emissions. A comprehensive tropospheric chemistry with 85 gas-phase species, 12 bulk aerosol species, 39 photolyses, and 157 gas-phase reactions has been included in MOZART-4 [24]. The chemical initial and boundary conditions, spatially and temporally varying $(6 \mathrm{~h})$, are constrained by global chemical transport simulations from MOZART-4/GEOS-5 (Goddard Earth Observing System-5) with $1.9^{\circ}$ latitude $\times 2.5^{\circ}$ longitude horizontal resolution and 56 vertical levels from the surface. Details on the meteorological data and emission inventory used for driving MOZART-4 as well as related configurations can be tracked in Emmons et al. [24]. We requested the MOZART output data from NCAR (National Center for Atmospheric Research, Boulder, CO, USA). The output data are varying $6 \mathrm{~h}$ (daily). We calculated the monthly data by averaging the daily data, and then used the monthly data for analysis.

\subsection{Satellite Derived Ground $\mathrm{NH}_{3}$ Measurements}

The fundamental thoughts of the methodology in this work were demonstrated in previous studies for aerosol [15-17], $\mathrm{NO}_{2}$ [19-21] and $\mathrm{SO}_{2}[19,25]$. The recent progress in satellite $\mathrm{NH}_{3}$ measurements also made this methodology applicable in estimating the ground $\mathrm{NH}_{3}$ concentrations by combining the $\mathrm{NH}_{3}$ profiles from CTM and $\mathrm{NH}_{3}$ columns.

We had three major steps to estimate the satellite-derived ground $\mathrm{NH}_{3}$ concentrations (Figure 2). First, we produced continuous monthly IASI $\mathrm{NH}_{3}$ columns according to the method in previous studies $[27,32]$. Second, we simulated the vertical profiles from MOZART-4, and calculated the ratio of ground $\mathrm{NH}_{3}$ to $\mathrm{NH}_{3}$ columns. Third, we derived the satellite-derived ground $\mathrm{NH}_{3}$ concentrations combining the IASI $\mathrm{NH}_{3}$ columns and the ratio in the second step. Of these three steps, the second step of simulating the vertical profiles was the most important and complex one. We demonstrate here the key algorithms to simulate the vertical profiles from MOZART.

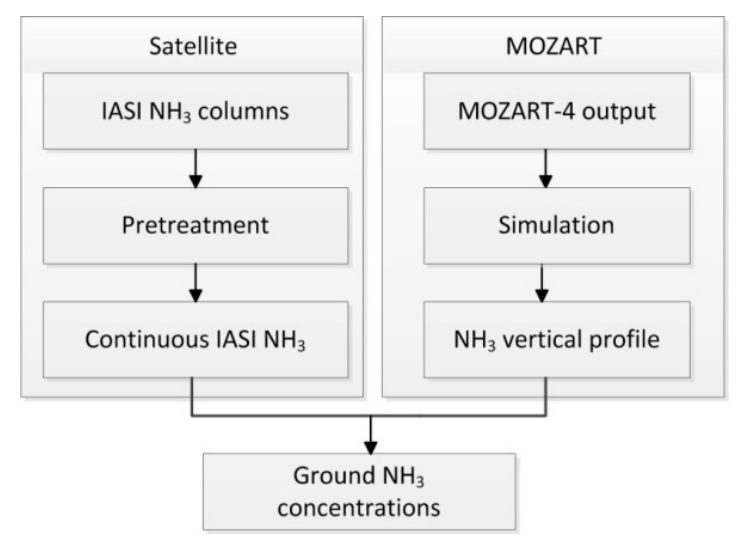

Figure 2. Schematic of the method to estimate the satellite-derived ground $\mathrm{NH}_{3}$ concentrations. 
We retrieved the $\mathrm{NH}_{3}$ profiles from MOZART to convert the IASI $\mathrm{NH}_{3}$ columns to ground $\mathrm{NH}_{3}$ concentrations. The $\mathrm{NH}_{3}$ vertical profile function was simulated by the following equation in the grid cell using the output data from MOZART-4:

$$
f(h)=\sum_{i=1}^{n} a_{i} e^{\frac{-\left(h-b_{i}\right)^{2}}{c_{i}^{2}}}
$$

where $n$ ranges from 2 to 6 , representing the number of Gaussian items; $a_{i}, b_{i}$, and $c_{i}$ indicate the constants for each Gaussian item; $h$ indicates the vertical height from the ground and $f(h)$ is the $\mathrm{NH}_{3}$ concentration at height $h$. Theoretically, we can use $n$ larger than 6 (with more Gaussian items). However, it is highly dependent on the computational time cost and computer memory limitations.

We simulated the $\mathrm{NH}_{3}$ vertical profile using Equation (1) by each grid cell, based on the 56 vertical layers of $\mathrm{NH}_{3}$ concentrations from MOZART. For each grid cell, we had five models $(n=2,3,4,5,6)$ and used $R^{2}$ and root-mean-square error (RMSE) to assess each model performance. We selected the best one with highest $\mathrm{R}^{2}$ and lowest RMSE (i.e., determined the value of $n$ ).

The MOZART $\mathrm{NH}_{3}$ columns can be gained by integration based on the simulated profile function:

$$
F\left(h_{\text {trop }}\right)=\int_{0}^{h_{\text {trop }}} f(h) d h
$$

where $F\left(h_{\text {trop }}\right)$ denotes $\mathrm{NH}_{3}$ columns and $h_{\text {trop }}$ indicates the tropospheric height.

The satellite-derived ground $\mathrm{NH}_{3}$ concentration is calculated as:

$$
\left[{ }_{S} \mathrm{NH}_{3}\right]_{G}=\left[{ }_{S} \mathrm{NH}_{3}\right]_{\text {Trop }} \times \frac{f\left(h_{G}\right)}{F\left(h_{\text {trop }}\right)}
$$

where $\left[{ }_{S} \mathrm{NH}_{3}\right]_{\text {Trop }}$ indicates the IASI $\mathrm{NH}_{3}$ columns, $f\left(h_{G}\right)$ denotes the ground $\mathrm{NH}_{3}$ concentration from MOZART, and $F\left(h_{\text {trop }}\right)$ represents the MOZART $\mathrm{NH}_{3}$ columns.

We used the national ground-based $\mathrm{NH}_{3}$ concentrations in NNDMN between 2010-2013 to validate the satellite-derived ground $\mathrm{NH}_{3}$ concentrations. We applied the correlation coefficient $(r)$ and relative error ((observation-estimation)/observation) at each monitoring site to assess the accuracy of the satellite-derived ground $\mathrm{NH}_{3}$ concentrations.

\section{Results and Discussion}

\subsection{Accuracy Assessment of the Estimated Ground $\mathrm{NH}_{3}$ Concentrations}

To convert the IASI $\mathrm{NH}_{3}$ columns to ground $\mathrm{NH}_{3}$ concentrations, it is essential to obtain the vertical $\mathrm{NH}_{3}$ profiles. We retrieved the vertical $\mathrm{NH}_{3}$ profiles from MOZART in this study (as an example, the vertical $\mathrm{NH}_{3}$ concentrations at five locations in January 2013 from MOZART are shown in Figure A1). The $\mathrm{NH}_{3}$ profiles were simulated by each grid cell in China (Figure A9) with determination of coefficients $\left(\mathrm{R}^{2}\right)$ larger than 0.95 accounting for $99.81 \%$ of all grid cells (Table A1 and Figure A9). Then, we estimated the ground $\mathrm{NH}_{3}$ concentrations based on IASI $\mathrm{NH}_{3}$ columns and the modeling MOZART $\mathrm{NH}_{3}$ profiles.

We used 44 ground-based sites from NNDMN between 2010-2013 to assess the performance of the estimated monthly ground $\mathrm{NH}_{3}$ concentrations. The correlation between the estimated and measured at each site is given in Table A2 in Appendix A, and the relative bias of each site as well as the yearly comparisons between the estimated and measured ground $\mathrm{NH}_{3}$ concentration are given in Figures 3 and 4 . We found $90.91 \%$ of minoring sites has a relative error within $-30 \%-50 \%$, showing an agreement between the estimated and measured. The seasonal absolute error by inverse-distance-weighted (IDW) interpolation is also shown in Figure A2. We found the absolute error in winter (December, January, and February) was higher than in other seasons, which can be explained 
by the highest relative error in $\mathrm{IASI} \mathrm{NH}_{3}$ columns in the winter season (Figure A3). In addition, Figure 4 demonstrates a comparison between the estimated and measured ground $\mathrm{NH}_{3}$ concentrations before and after applying the IASI $\mathrm{NH}_{3}$ data. We found a relatively higher correlation ( $\left.\mathrm{R}, 0.81 \mathrm{vs.} 0.57\right)$ and a better consistency (slope, 0.96 vs. 0.50) between the satellite-derived ground $\mathrm{NH}_{3}$ concentrations and the measured ground $\mathrm{NH}_{3}$ concentrations than those from MOZART not applying the IASI $\mathrm{NH}_{3}$ data.

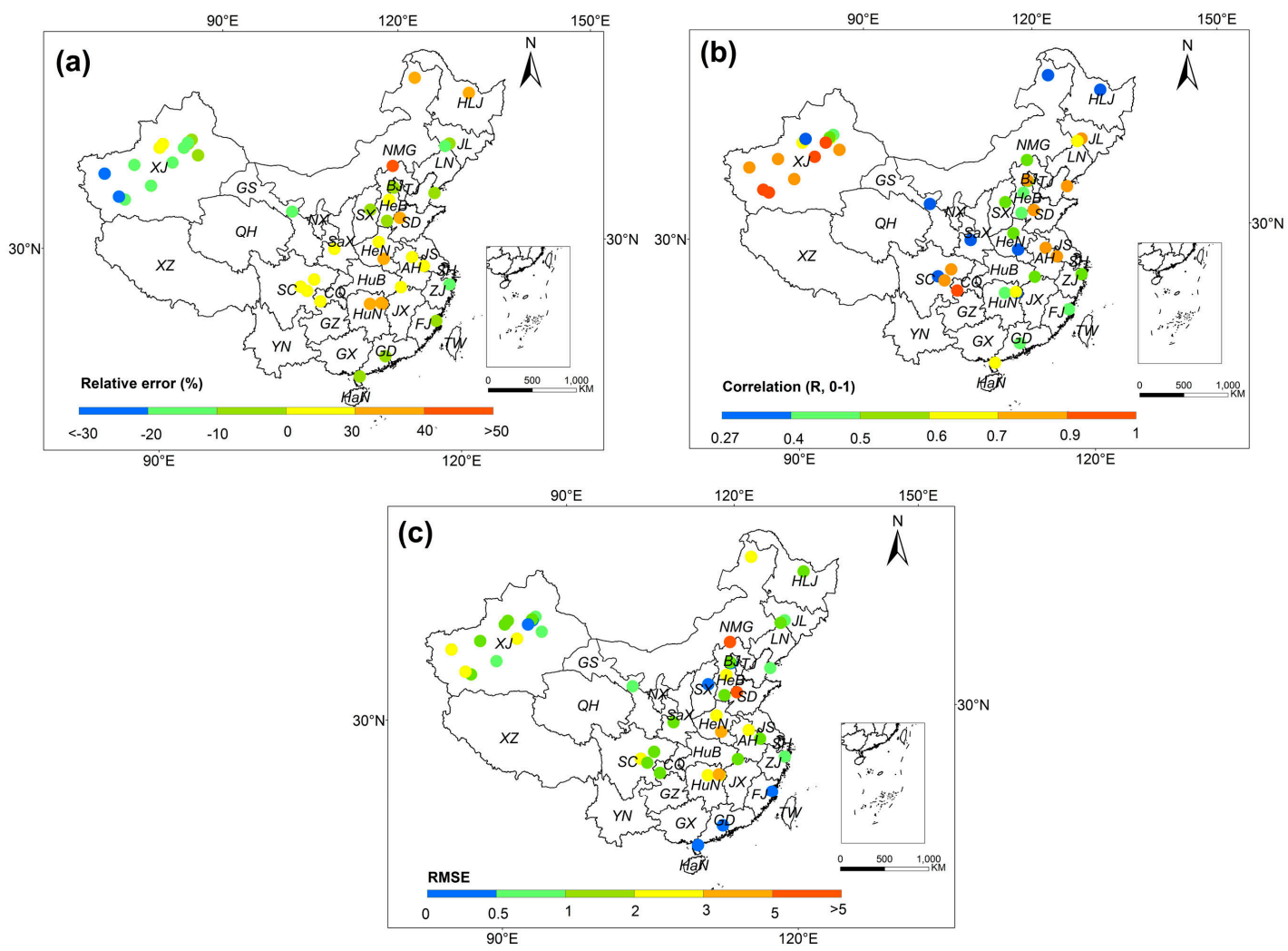

Figure 3. Spatial distribution of the relative error (a), correlation (b) and root-mean-square error (RMSE) (c) of the estimated ground $\mathrm{NH}_{3}$ concentration $\left(\mu \mathrm{g} \mathrm{N} \mathrm{m}{ }^{-3}\right)$ at $44 \mathrm{NNDMN}$ sites.

(a) Validation not applying satellite data

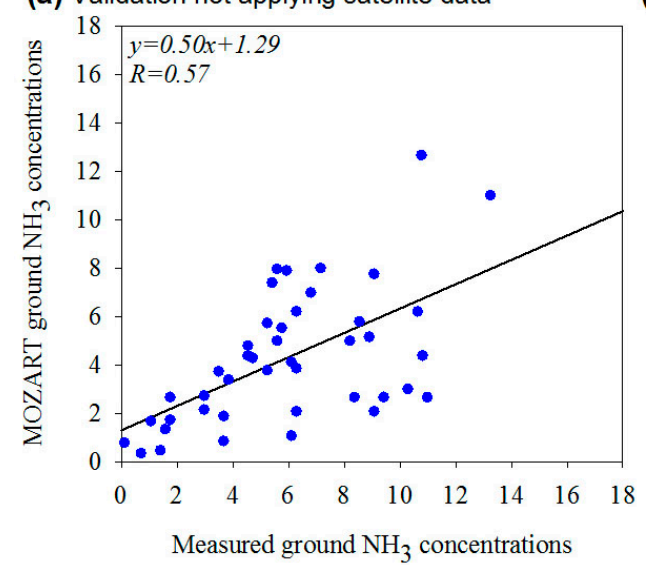

(b) Validation by applying satellite data

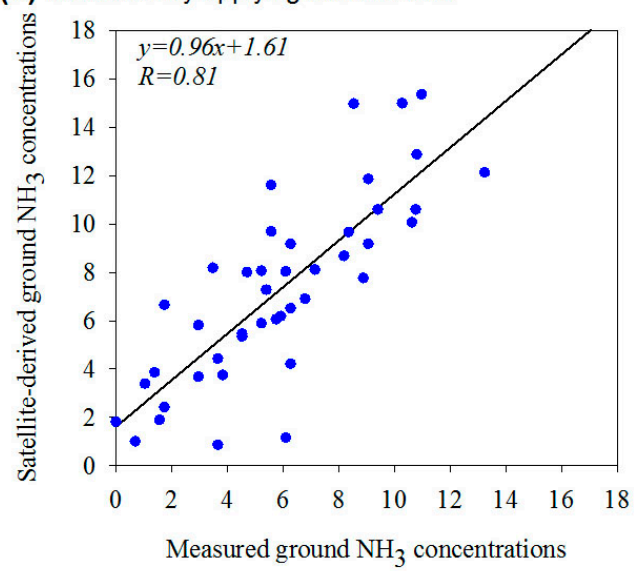

Figure 4. Yearly comparisons between the estimated and measured ground $\mathrm{NH}_{3}$ concentration ( $\mu \mathrm{g} \mathrm{N} \mathrm{m}^{-3}$ ). (a) indicates the comparison between the measured ground $\mathrm{NH}_{3}$ concentrations and the estimated ground $\mathrm{NH}_{3}$ concentrations from MOZART at the lowest layer before applying the satellite data, while (b) represents the comparison between the measured and estimated ground $\mathrm{NH}_{3}$ concentrations by applying the satellite data using the methods in Section 2.4. 


\subsection{Spatial Pattern of the Ground $\mathrm{NH}_{3}$ Concentrations}

Spatial distribution of ground $\mathrm{NH}_{3}$ concentrations in 2012 over China is shown in Figure 5a. High ground $\mathrm{NH}_{3}$ concentrations greater than $10 \mu \mathrm{g} \mathrm{N} \mathrm{m}{ }^{-3}$ were concentrated in North China and South China including Beijing-Tianjin-Hebei (BTH), Shandong, Henan, Hubei, Anhui, Sichuan and Jiangsu provinces, forming the major regions of intensive agriculture over China. Low ground $\mathrm{NH}_{3}$ concentrations are predominantly located in TP (Tibetan Plateau), where both the synthetic fertilizers and livestock waste were the least among 32 provinces $[34,35]$. The spatial ground $\mathrm{NH}_{3}$ concentrations revealed considerable spatial heterogeneity across China and were in agreement with the percent farmland area (Figure 5a,b), reflecting its unique agricultural structure and farming practice.
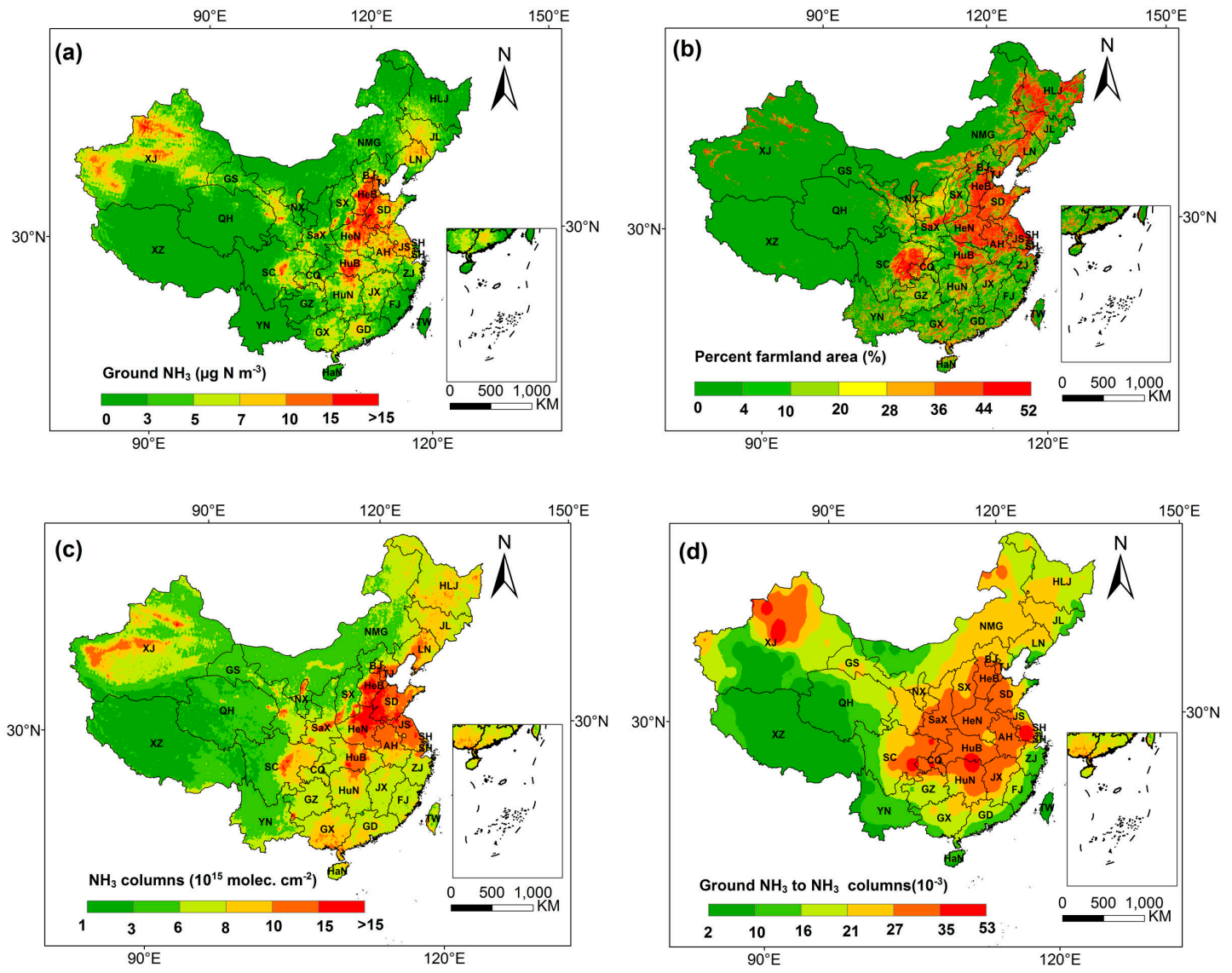

Figure 5. Spatial distribution of the ground $\mathrm{NH}_{3}$ concentration $\left(\mu \mathrm{g} \mathrm{N} \mathrm{m}{ }^{-3}\right)$. (a) represents the yearly estimated ground $\mathrm{NH}_{3}$ concentrations; (b) denotes the percent farmland area; (c) denotes the Infrared Atmospheric Sounding Interferometer (IASI) $\mathrm{NH}_{3}$ columns and (d) indicates the ratio of ground $\mathrm{NH}_{3}$ concentration to $\mathrm{NH}_{3}$ columns from MOZART.

High ground $\mathrm{NH}_{3}$ concentrations were also observed in some areas in Xinjiang province (Figure $5 \mathrm{a}$ ), where our estimation were about $-30 \%$ to $-10 \%$ underestimation compared with measurements in NNDMN (Figure 3). Moreover, relatively high $\mathrm{NH}_{3}$ columns could be observed by satellite IASI instrument (Figure 5c). Synthetic $\mathrm{N}$ fertilizers and livestock waste both dominated the spatial distribution of the total emissions [34,35], hence determining the spatial patterns of the ground $\mathrm{NH}_{3}$ concentrations. Previous studies reported that the $\mathrm{NH}_{3}$ emissions from livestock exceeded those from the farmland in China, and $\mathrm{NH}_{3}$ emissions from livestock accounted for about $54 \%$ of the total $\mathrm{NH}_{3}$ emissions over China [35]. The contribution of livestock to the total $\mathrm{NH}_{3}$ emissions in Xinjiang (where sheep are widely raised) accounted for higher than $60 \%[10,35]$. Thus, due to the combining influence of both synthetic $\mathrm{N}$ fertilizers and livestock waste, the spatial distributions of ground $\mathrm{NH}_{3}$ 
concentrations and percent farmland differed, especially in regions where the livestock dominated the $\mathrm{NH}_{3}$ emissions. In addition, most of the ground $\mathrm{NH}_{3}$ emissions were more concentrated on the ground and relatively hard to transport vertically compared with other regions in China, which can be clearly seen by the ratio of ground $\mathrm{NH}_{3}$ concentrations to $\mathrm{NH}_{3}$ columns from MOZART (Figure 5d).

\subsection{Seasonal Variations of the Ground $\mathrm{NH}_{3}$ Concentrations in China}

To demonstrate the seasonal variations of the ground $\mathrm{NH}_{3}$ concentrations in China, we calculated the monthly average values throughout China (Figure 6a). We found the maximum ground $\mathrm{NH}_{3}$ concentrations over China occurred in summer (June, July, and August), followed by spring (March, April, and May), autumn (September, October, and November) and winter (December, January, and February) seasons. It is interesting that the seasonal ground $\mathrm{NH}_{3}$ concentrations were in agreement with the seasonal patterns of $\mathrm{NH}_{3}$ emissions in China conducted by Kang et al. [36], Huang et al. [35], and $\mathrm{Xu}$ et al. [37] (Figure $6 \mathrm{~b}-\mathrm{d}$ ), indicating that the $\mathrm{NH}_{3}$ emissions are the key factor influencing seasonal pattern of the ground $\mathrm{NH}_{3}$ concentrations. The maximum $\mathrm{NH}_{3}$ emissions in summer is reasonable due to more than $40 \%$ of the fertilization and more than $25 \%$ of livestock emissions occurring in summer [36,37]. In addition, high temperature in summer in China may also accelerate the $\mathrm{NH}_{3}$ volatilization $\left(\mathrm{NH}_{4}{ }^{+} \rightarrow \mathrm{NH}_{3}+\mathrm{H}^{+}\right)$from fertilizer, animal waste, city garbage or vehicles [6,38-40], and hence cause high ground $\mathrm{NH}_{3}$ concentrations. In contrast, in winter, temperature frequently below freezing leads to reduced $\mathrm{NH}_{3}$ volatilization and lower $\mathrm{NH}_{3}$ concentrations than in other seasons.

(a) This study

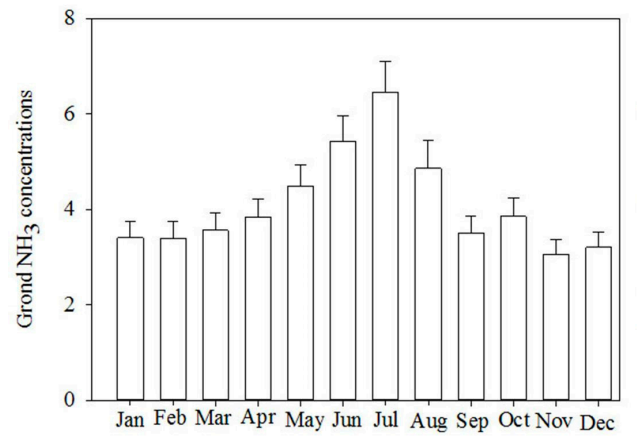

(c) Huang et al., 2012

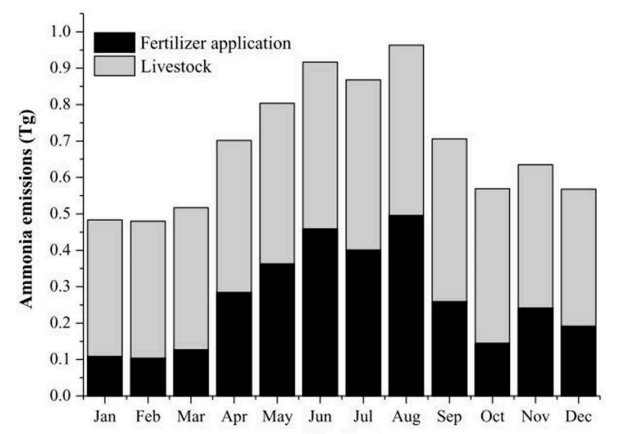

(b) Kang et al., 2016

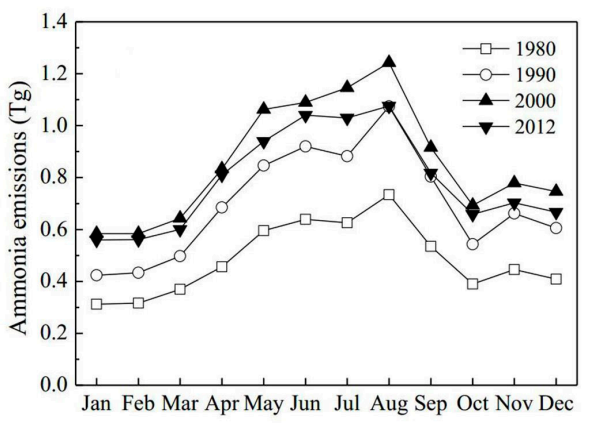

(d) Xu et al., 2015

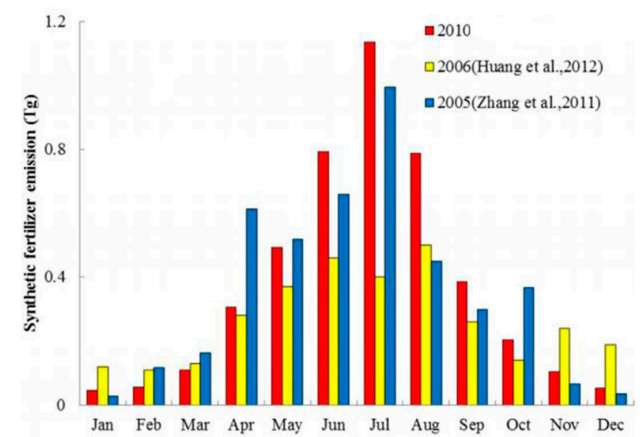

Figure 6. Seasonal patterns of ground $\mathrm{NH}_{3}$ concentrations in China. (a) indicates the monthly variations of ground $\mathrm{NH}_{3}$ concentrations $\left(\mu \mathrm{g} \mathrm{N} \mathrm{m}^{-3}\right.$ ) in China; (b) represents the monthly variations of the total $\mathrm{NH}_{3}$ emissions ( $\mathrm{Tg}, 10^{12} \mathrm{~g}$ ) in China conducted by Kang et al. [36]; (c) shows the the monthly variations of the sum of fertilizer and livestock $\mathrm{NH}_{3}$ emissions (Tg) in China conducted by Huang et al. [35] and (d) denotes the monthly variations of the fertilizer $\mathrm{NH}_{3}$ emissions ( $\mathrm{Tg}$ ) in China conducted by Xu et al. [37].

To more accurately quantify the effects of meteorological parameters on the seasonal trends of the ground $\mathrm{NH}_{3}$ concentrations, we selected the five best-simulated ground sites with $n>30$ 
(Table A2) for demonstrating meteorological parameters, such as temperature, wind speed, humidity, and precipitation on the seasonal variations of the ground $\mathrm{NH}_{3}$ concentrations (Figures 7 and A4-A8). The monthly wind speed, temperature, relative humidity, and precipitation for each site were taken from the China Meteorological Administration. A positive correlation $(R=0.6, p=0.00)$ was found between the ground $\mathrm{NH}_{3}$ concentrations and temperature. An inverse relationship between the ground $\mathrm{NH}_{3}$ concentrations and humidity (Figure 7), indicated that higher relative humidity may contribute to more $\mathrm{NH}_{3}$ loss rates $\left(\mathrm{NH}_{3} \rightarrow \mathrm{NH}_{4}{ }^{+}\right)$. In addition, we also conducted a partial correlation analysis [41] regarding ground $\mathrm{NH}_{3}$ concentrations, temperature, and humidity by considering their interactions using the function "partialcorr" in Matlab. We found the partial correlation between ground $\mathrm{NH}_{3}$ concentrations and humidity was $-0.10(p=0.03)$, showing a significant inverse relationship between the ground $\mathrm{NH}_{3}$ concentrations and humidity. Significant effects of air humidity on $\mathrm{NH}_{3}$ loss were also demonstrated previously [42,43]. However, precipitation and wind speed were not significantly correlated with ground $\mathrm{NH}_{3}$ concentrations ( $p=0.632$, precipitation vs. $\mathrm{NH}_{3} ; p=0.156$, wind speed vs. $\mathrm{NH}_{3}$ ) as shown in Figures A4-A8.
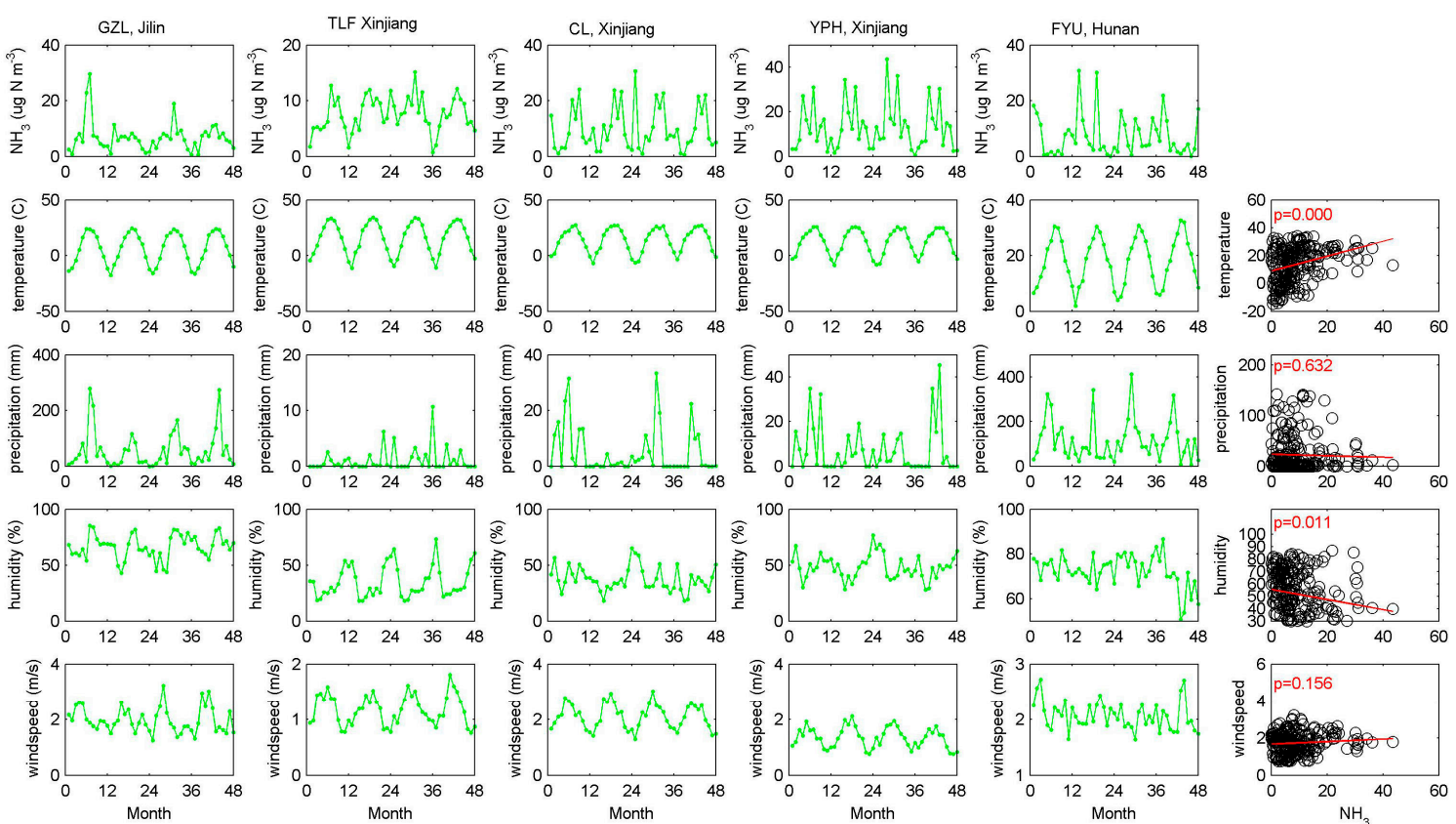

Figure 7. The seasonal variations of ground $\mathrm{NH}_{3}$ concentrations $\left(\mu \mathrm{g} \mathrm{N} \mathrm{m}{ }^{-3}\right)$, temperature $\left({ }^{\circ} \mathrm{C}\right)$, precipitation $(\mathrm{mm})$, humidity $(\%)$, and wind speed $(\mathrm{m} / \mathrm{s})$ at five sites with best-simulated ground $\mathrm{NH}_{3}$ concentrations from January 2010 to December 2013 (0-12, 2010; 13-24, 2011; 25-36, 2012; 37-48, 2013). The relationship between the ground $\mathrm{NH}_{3}$ concentrations and precipitation (mm), humidity (\%), and wind speed $(\mathrm{m} / \mathrm{s})$ at each site is provided in Figures A4-A8.

\subsection{Comparison with Previous Studies}

The first relatively complete work on the national ground measurements of $\mathrm{NH}_{3}$ concentrations in China is NNDMN, and the results of ground measurements were published by $\mathrm{Xu}$ et al. [30], which we considered as a truly comprehensive and valuable work on the national status of the ground $\mathrm{NH}_{3}$ concentrations, and which shed some light on the actual status of ground $\mathrm{NH}_{3}$ concentrations. The national measurements in NNDMN provide the best accurate datasets for validating the modeling ground $\mathrm{NH}_{3}$ concentrations. In the previous studies, due to very limited ground measurements (not to mention the national monitoring measurements), it was difficult to validate the accuracy of the modeling ground $\mathrm{NH}_{3}$ concentrations in China. The lack of measurements makes it necessary to assess the modeling ground $\mathrm{NH}_{3}$ concentrations in China [44]. Recently, Zhao et al. [45] presented 
a comprehensive work on the national-scale model validation of ground $\mathrm{NH}_{3}$ concentrations with $1 / 2^{\circ}$ longitude by $1 / 3^{\circ}$ latitude horizontal resolution using the GEOS-Chem model, showing the correlation coefficient with NNDMN between 2011-2012 which was about 0.65 on the annual scale [45]. Compared with Zhao et al. [45], we used the same datasets from NNDMN while having a longer time period (2010-2013) to validate our estimated ground $\mathrm{NH}_{3}$ concentrations, and found the correlation coefficient was about 0.81 (slope $=0.96$ and intercept $=1.31$ ) on the annual scale as shown in Figure 4, demonstrating better agreement with the ground measurements. The relatively higher accuracy in estimating ground $\mathrm{NH}_{3}$ concentrations may result from different datasets used for estimation, where we used the satellite observation and Zhao et al. [45] used the $\mathrm{NH}_{3}$ emission data used for modeling. Uncertainties existed in the estimation of $\mathrm{NH}_{3}$ emission resulting from the methodology of calculation, which simplified the complexity of the real status of emission process [36]. For example, $\mathrm{N}$-fertilizer $\mathrm{NH}_{3}$ emission in BTH between different studies varied greatly as $256.5 \mathrm{Gg}$ [35], $502.5 \mathrm{Gg}$ [46], $432.7 \mathrm{Gg}$ [10]; livestock $\mathrm{NH}_{3}$ emission in BTH between different studies varied as $556.6 \mathrm{Gg}$ [35], $675.2 \mathrm{Gg}$ [46], and $891.6 \mathrm{Gg}$ [10]. The estimation of $\mathrm{NH}_{3}$ emissions by Zhou et al. [10] even nearly doubled that by Huang et al. [35] and Dong et al. [46]. The actual local emission factors in different regions differed from each other greatly, due to the difference of the local meteorological conditions, fertilizing time, and fertilizer kinds [37]. The $\mathrm{NH}_{3}$ emissions are mainly based on statistical $\mathrm{NH}_{3}$ emissions at a city or county level, and the accuracy is strongly dependent on both the limited spatial and temporal resolutions of the coarse statistical data [35-37,44,47].

The present study derived ground $\mathrm{NH}_{3}$ concentrations from IASI $\mathrm{NH}_{3}$ columns and the profiles from MOZART-4, implying that a combination of CTM modeling and satellite monitoring obtained a reliable ground $\mathrm{NH}_{3}$ estimation over China. More generally, this attempt to generate the ground $\mathrm{NH}_{3}$ measurements with a relative high resolution from IASI and MOZART has highlighted known limitations in the ground $\mathrm{NH}_{3}$ monitoring measurements, which may in some cases not be representative of the estimated $\mathrm{NH}_{3}$ concentrations horizontally and vertically. Here we highlight the need to acquire more comprehensive datasets of ground $\mathrm{NH}_{3}$ concentrations, and dedicated measurement campaigns focusing on the ground $\mathrm{NH}_{3}$ measurement will no doubt allow improvements in the validation of estimated $\mathrm{NH}_{3}$ in the future. In addition, we focused on the spatial pattern of ground $\mathrm{NH}_{3}$ concentrations derived from satellite and a CTM, which is based on the monthly average and may be limited for the specific analysis such as secondary aerosol formation, photochemistry, and consideration of regulation. It is also beneficial and even essential to gain higher temporal resolution of ground $\mathrm{NH}_{3}$ concentrations in the future.

\section{Conclusions}

We critically estimated the ground $\mathrm{NH}_{3}$ concentrations over China, combining IASI $\mathrm{NH}_{3}$ columns and $\mathrm{NH}_{3}$ profiles from MOZART. We aimed to generate ground $\mathrm{NH}_{3}$ concentrations over China, and hence provide potential to understand both the spatial and temporal variations of ground $\mathrm{NH}_{3}$ concentrations in order to guide future ground $\mathrm{NH}_{3}$ monitoring plans. The intention was not to replace traditional algorithms but to provide new insight on the current status of ground $\mathrm{NH}_{3}$ over China, and to generate more reliable ground $\mathrm{NH}_{3}$ concentrations. The IASI $\mathrm{NH}_{3}$ columns and $\mathrm{NH}_{3}$ profiles from the atmospheric chemistry transport model are encouraged to be combined to generate ground $\mathrm{NH}_{3}$ concentrations at local or regional scales, and the estimated results should be further improved.

This study introduced methods to estimate ground $\mathrm{NH}_{3}$ concentrations over China using IASI $\mathrm{NH}_{3}$ columns and $\mathrm{NH}_{3}$ profiles. The estimated ground $\mathrm{NH}_{3}$ concentrations were validated by 44 sites from NNDMN, showing promising results between the estimated and measured, and then the spatial and temporal variations of ground $\mathrm{NH}_{3}$ concentrations were demonstrated. High ground $\mathrm{NH}_{3}$ concentrations greater than $10 \mu \mathrm{g} \mathrm{N} \mathrm{m}{ }^{-3}$ were mainly located in Beijing, Hebei, Shandong, Henan, Jiangsu, eastern Sichuan, and some regions in Xinjiang provinces, while low ground $\mathrm{NH}_{3}$ concentrations were concentrated in the Tibet-Plateau area. The maximum ground $\mathrm{NH}_{3}$ concentrations 
over China occurred in summer, followed by spring, autumn, and winter seasons, which are in agreement with the seasonal patterns of $\mathrm{NH}_{3}$ emissions in China.

Acknowledgments: This study was supported by the National Natural Science Foundation of China (No. 41471343, 40425007 and 41101315) and Doctoral Research Innovation Fund (2016CL07). We also much appreciate the free use of the IASI $\mathrm{NH}_{3}$ data provided by Université Libre de Bruxelles (ULB) (http:/ / www.ulb.ac.be/cpm/ atmosphere.html).

Author Contributions: L.L. and X.Z conceived the idea; L.L. and S.W. conducted the analyses; L.L. and S.W. processed the data; X.L. and W.X. provided the observation data for validation; X.Z, X.L., L.Z., and W.Z. contributed to the writing and revisions.

Conflicts of Interest: The authors declare no competing financial interest.

\section{Appendix A}

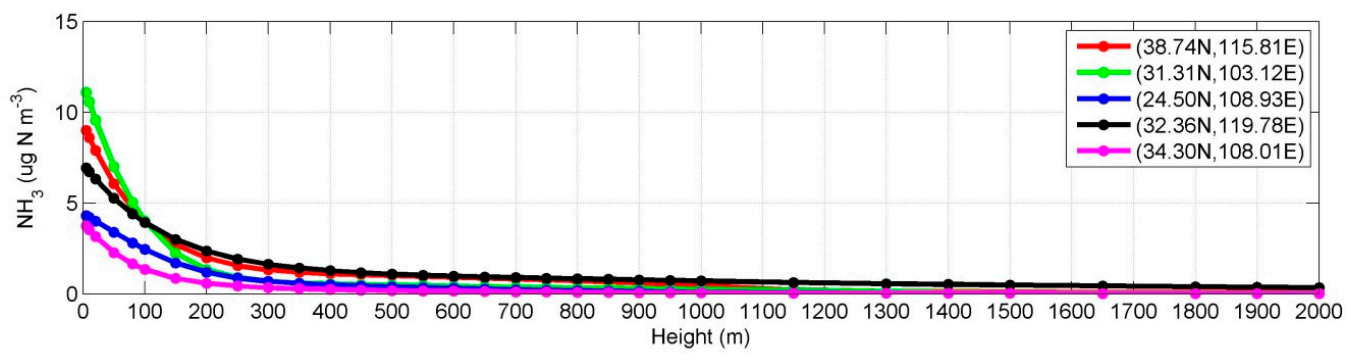

Figure A1. Vertical $\mathrm{NH}_{3}$ concentrations $\left(\mu \mathrm{g} \mathrm{N} \mathrm{m}^{-3}\right.$ ) simulated by Mozart at five locations in January 2013.
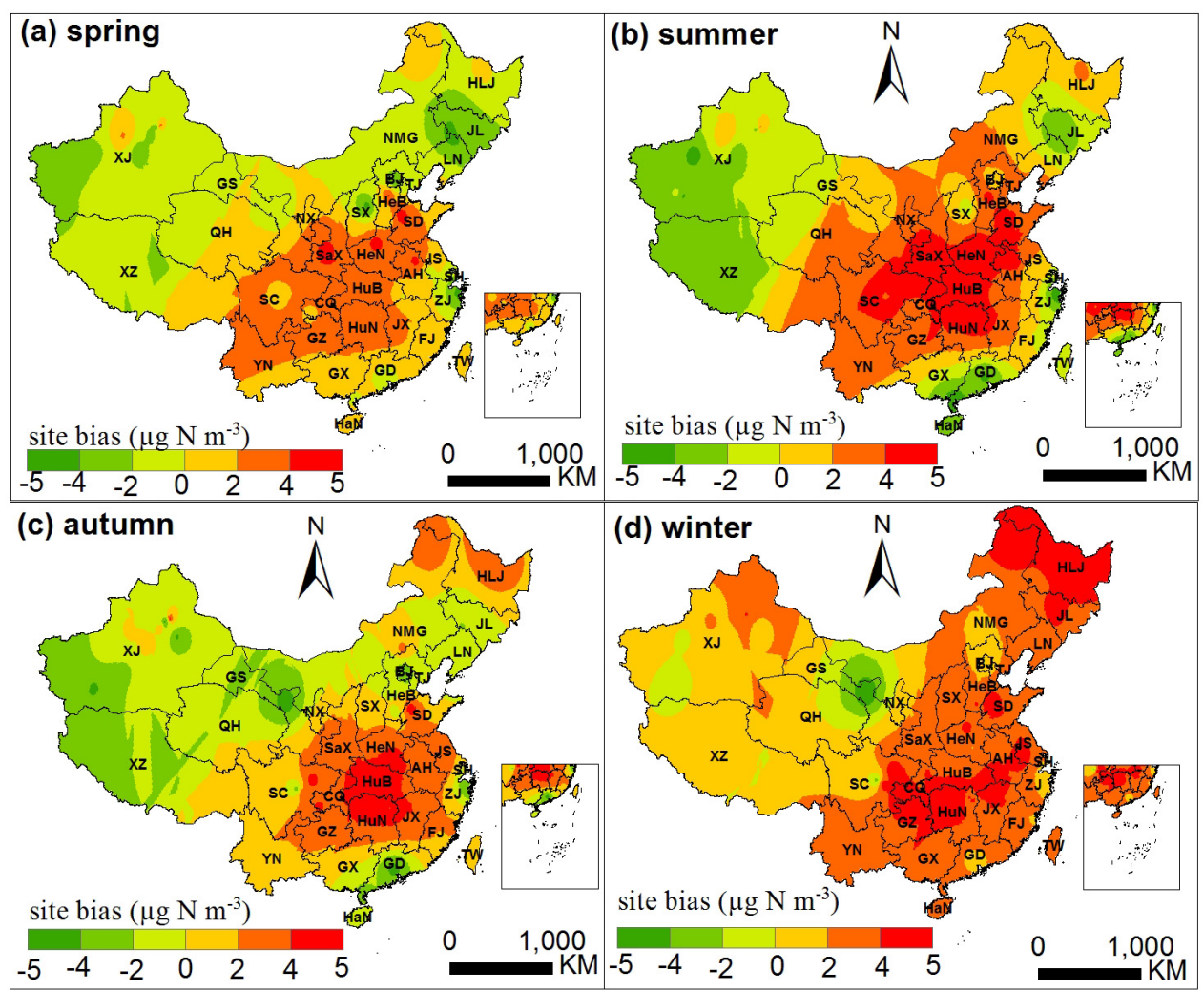

Figure A2. A quick illustration of the site bias of ground $\mathrm{NH}_{3}$ concentrations across China by interpolating the residuals between the measured and estimated using the inverse-distance-weighted (IDW) interpolation. The figures were generated using ArcGIS 12.0 software (https://www.arcgis.com/). 

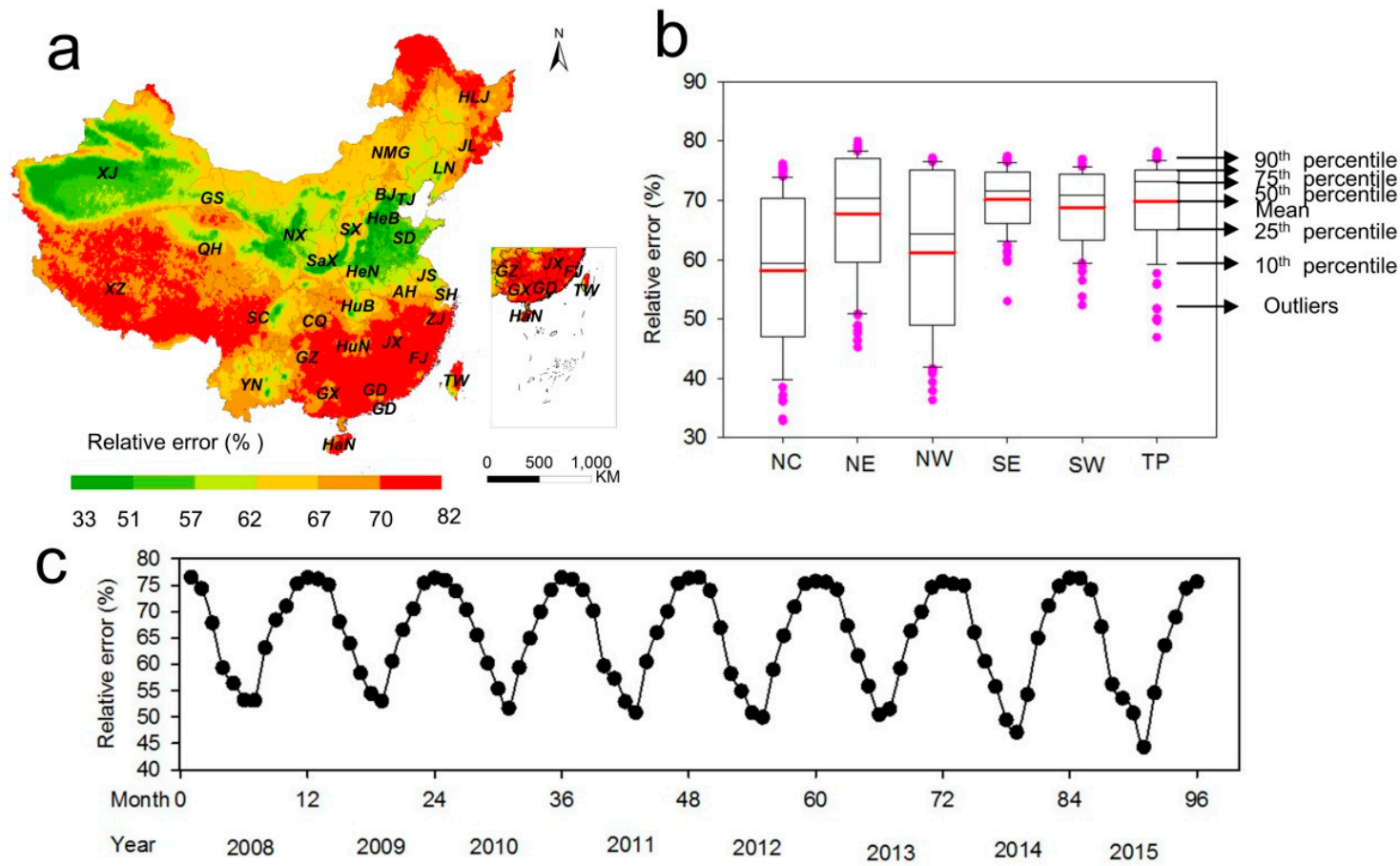

Figure A3. Relative error (\%) of IASI $\mathrm{NH}_{3}$ columns. (a) indicates the annual IASI $\mathrm{NH}_{3}$ error (with a cloud coverage lower than 25\%) averaged from 2008 to 2015; (b) indicates the averaged monthly relative error from 2008 to 2015 in different regions (every dot indicates the relative error at a month in a region); (c) indicates the temporal variations of relative error over China at a monthly scale.
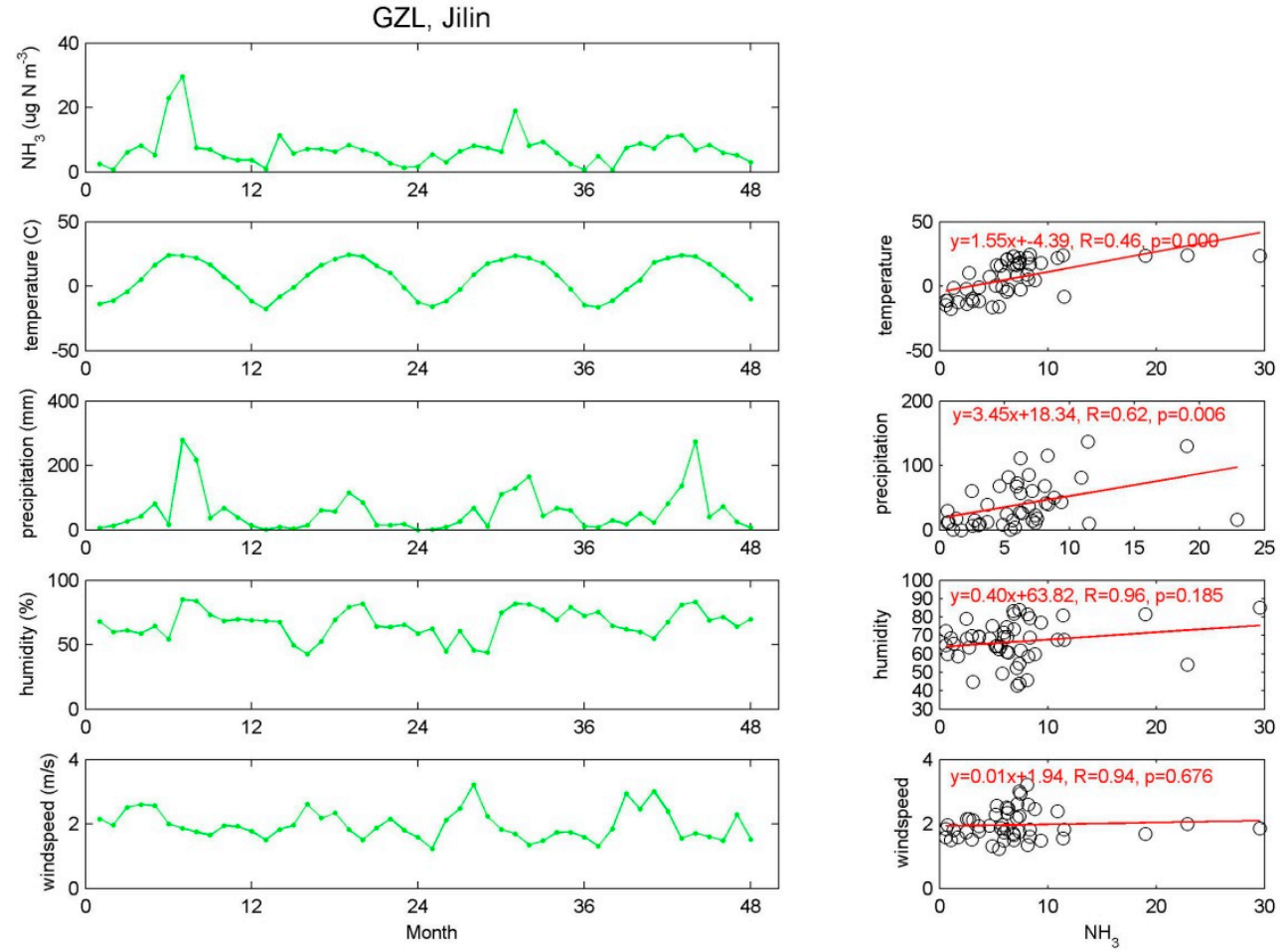

Figure A4. The seasonal variations of ground $\mathrm{NH}_{3}$ concentrations $\left(\mu \mathrm{g} \mathrm{N} \mathrm{m}{ }^{-3}\right)$, temperature $\left({ }^{\circ} \mathrm{C}\right)$, precipitation (mm), humidity (\%), and wind speed (m/s) at GZL from January 2010 to December 2013 (0-12, 2010; 13-24, 2011; 25-36, 2012; 37-48, 2013). 

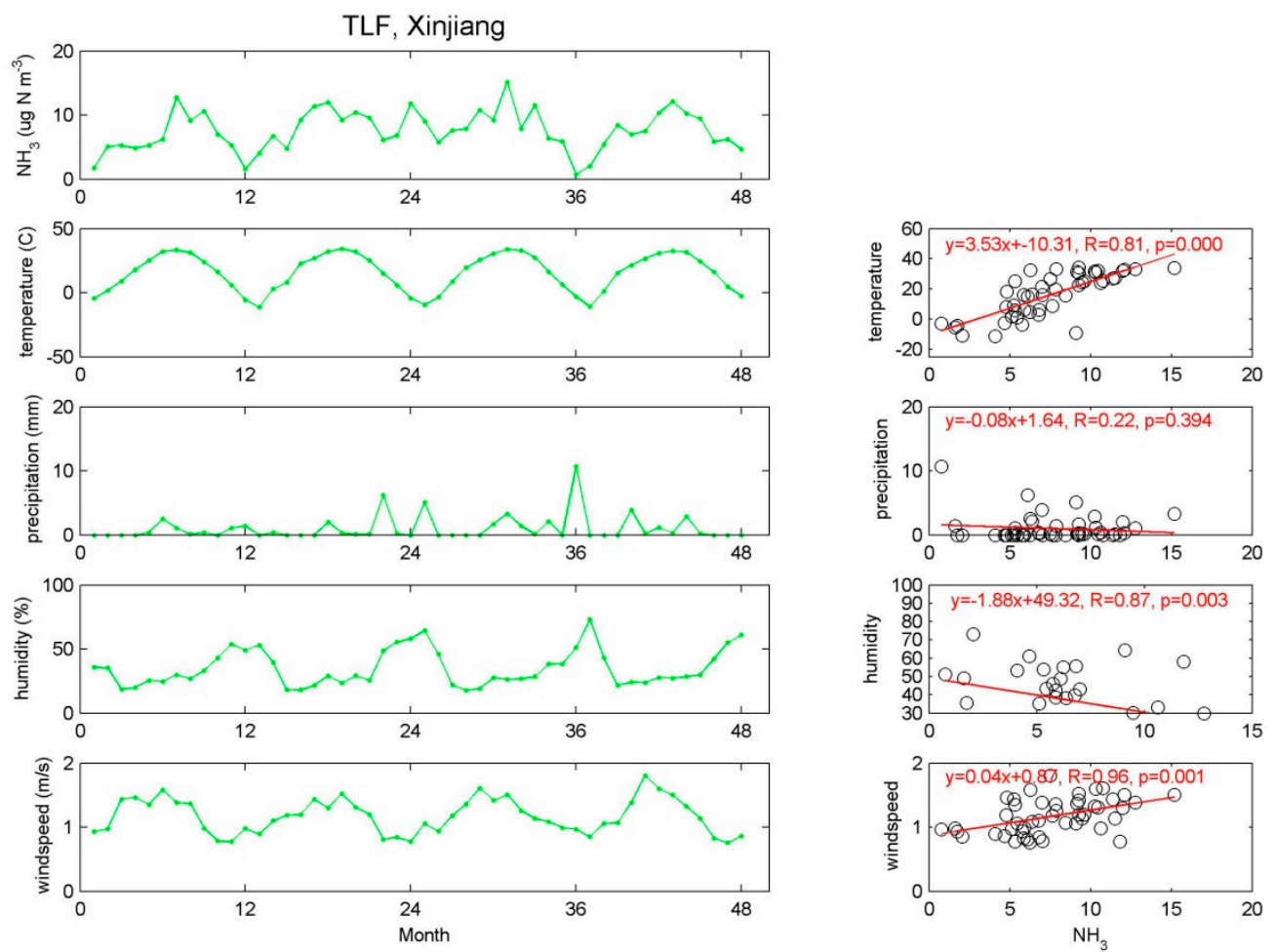

Figure A5. The seasonal variations of ground $\mathrm{NH}_{3}$ concentrations $\left(\mu \mathrm{g} \mathrm{N} \mathrm{m}{ }^{-3}\right)$, temperature $\left({ }^{\circ} \mathrm{C}\right)$, precipitation (mm), humidity (\%), and wind speed (m/s) at TLF from January 2010 to December 2013 (0-12, 2010; 13-24, 2011; 25-36, 2012; 37-48, 2013).
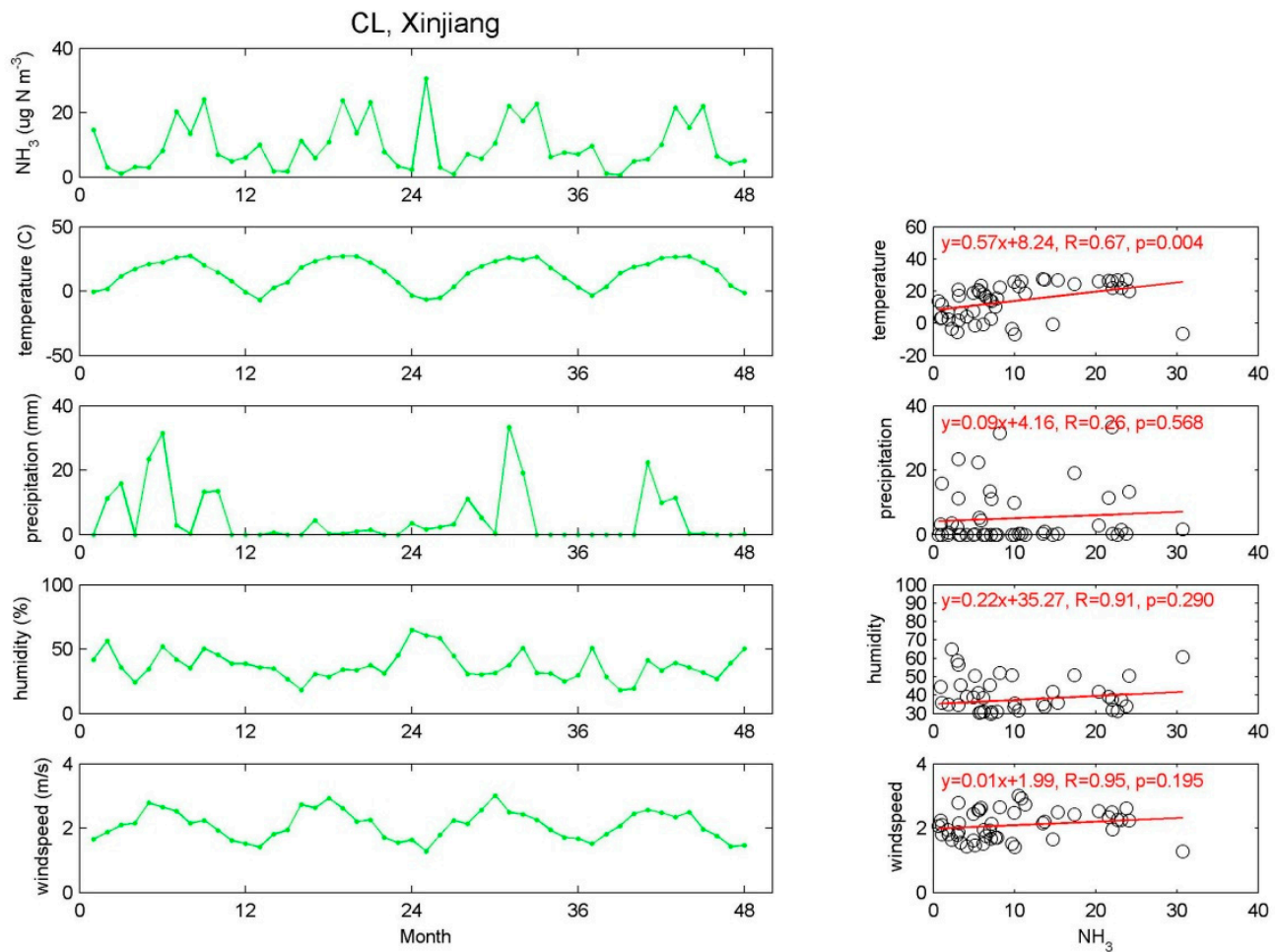

Figure A6. The seasonal variations of ground $\mathrm{NH}_{3}$ concentrations $\left(\mu \mathrm{g} \mathrm{N} \mathrm{m}{ }^{-3}\right)$, temperature $\left({ }^{\circ} \mathrm{C}\right)$, precipitation $(\mathrm{mm})$, humidity $(\%)$, and wind speed $(\mathrm{m} / \mathrm{s})$ at CL from January 2010 to December 2013 $(0-12,2010 ; 13-24,2011 ; 25-36,2012 ; 37-48,2013)$. 

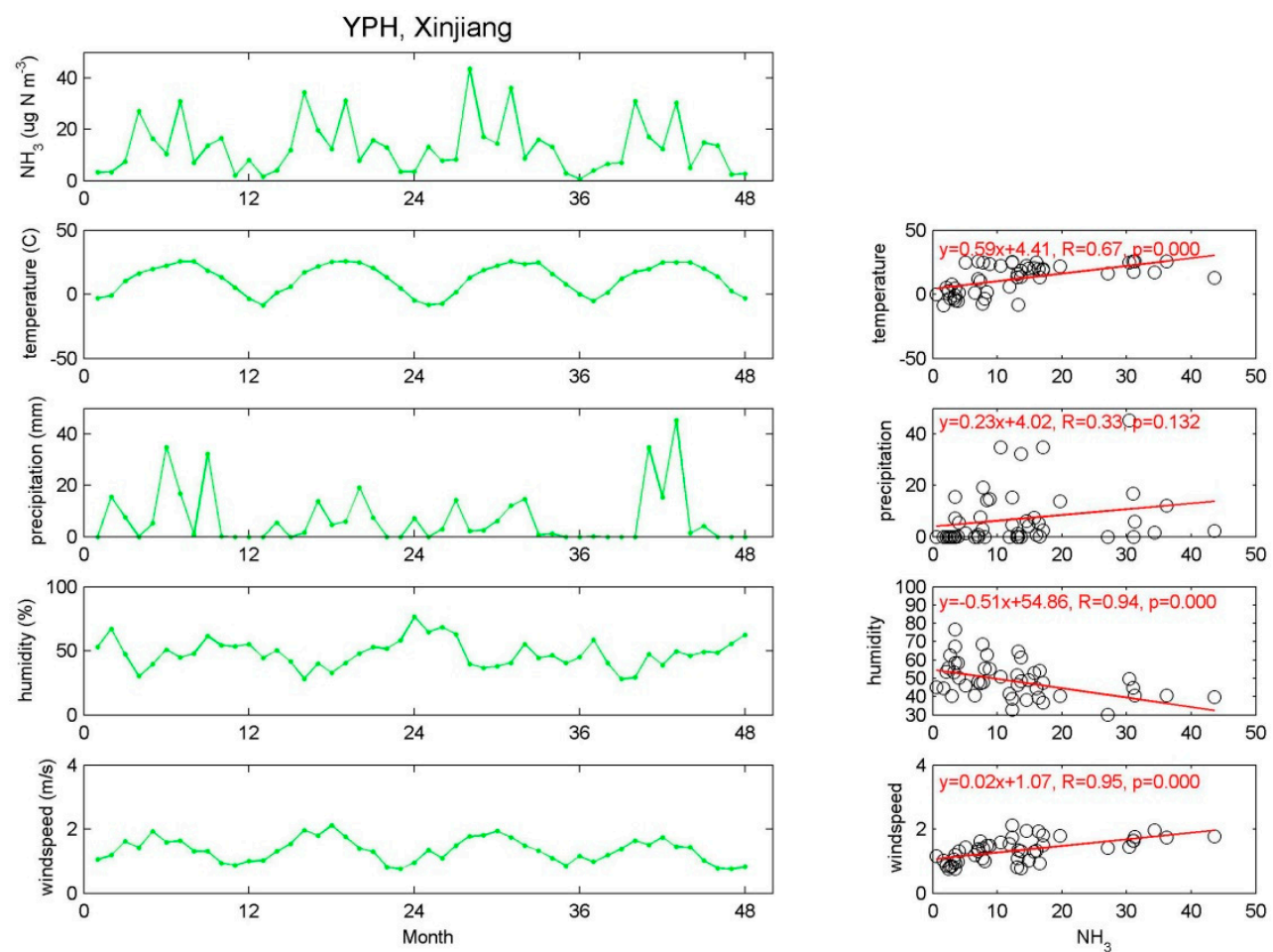

Figure A7. The seasonal variations of ground $\mathrm{NH}_{3}$ concentrations $\left(\mu \mathrm{g} \mathrm{N} \mathrm{m}{ }^{-3}\right)$, temperature $\left({ }^{\circ} \mathrm{C}\right)$, precipitation $(\mathrm{mm})$, humidity $(\%)$, and wind speed $(\mathrm{m} / \mathrm{s})$ at YPH from January 2010 to December 2013 (0-12, 2010; 13-24, 2011; 25-36, 2012; 37-48, 2013).
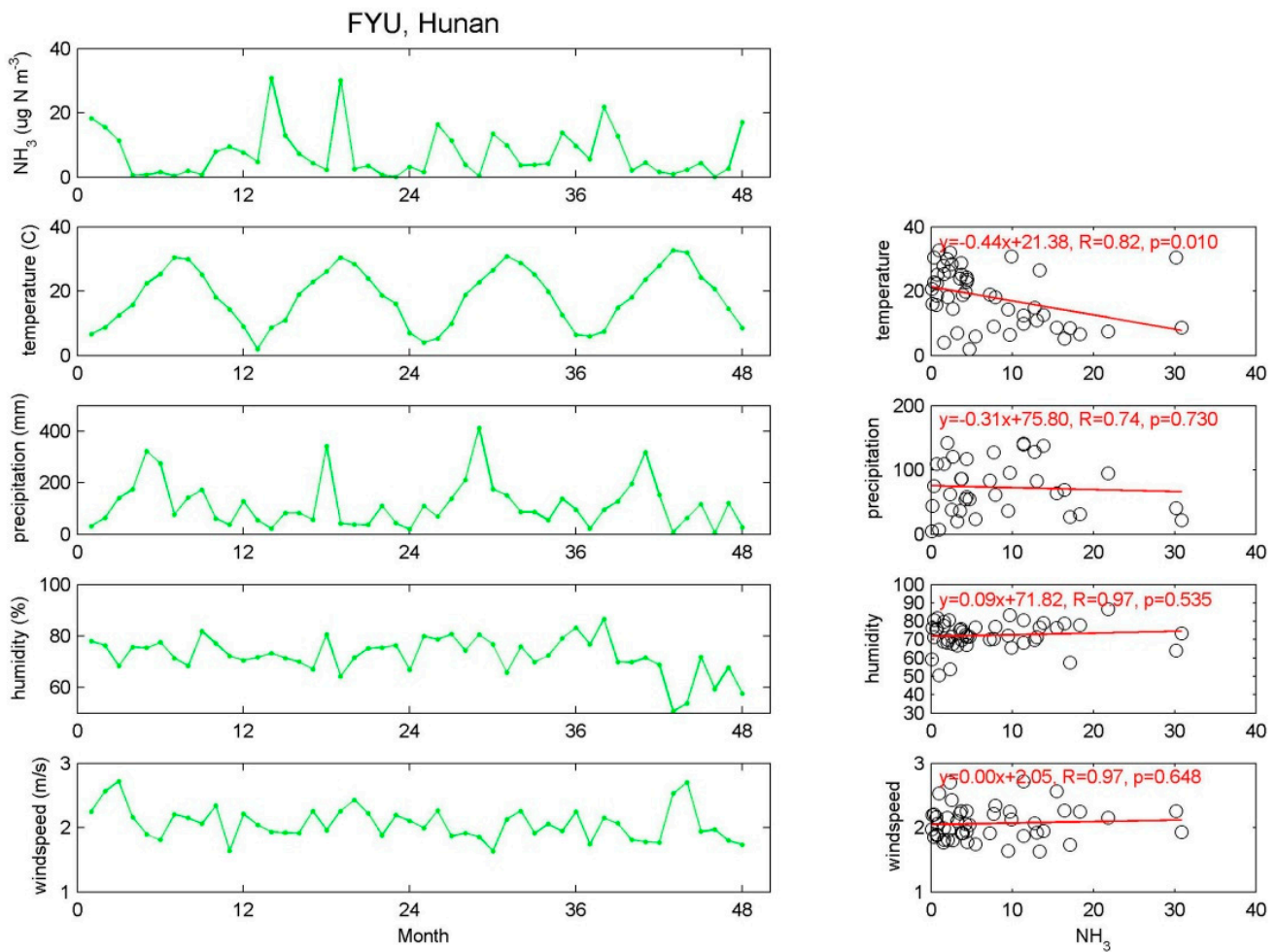

Figure A8. The seasonal variations of ground $\mathrm{NH}_{3}$ concentrations $\left(\mu \mathrm{g} \mathrm{N} \mathrm{m}{ }^{-3}\right)$, temperature $\left({ }^{\circ} \mathrm{C}\right)$, precipitation (mm), humidity (\%), and wind speed (m/s) at FYU from January 2010 to December 2013 (0-12, 2010; 13-24, 2011; 25-36, 2012; 37-48, 2013). 


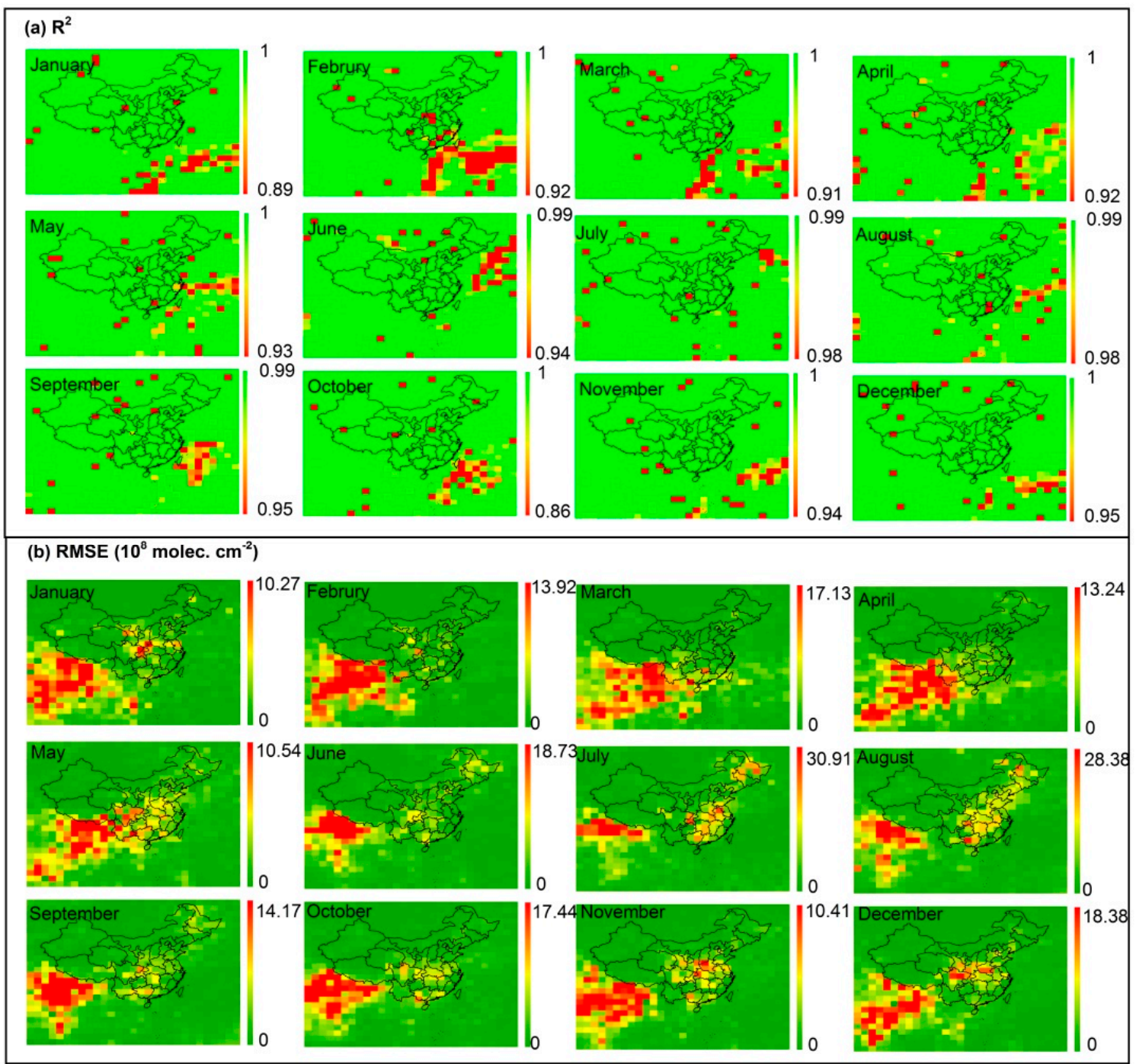

Figure A9. $(\mathbf{a}, \mathbf{b}) \mathrm{R}^{2}$ and RMSE (molec. $\left./ \mathrm{cm}^{2}\right)$ for the Gaussian simulation of the $\mathrm{NH}_{3}$ profiles $\left(68 \sim 142^{\circ} \mathrm{E}\right.$, $\left.5 \sim 55^{\circ} \mathrm{N}\right)$ in 2013.

Table A1. Descriptive statistics for results of Gaussian simulation.

\begin{tabular}{cccccccc}
\hline Season (\%) & $\mathbf{N = \mathbf { 2 }}$ & $\mathbf{N = 3}$ & $\mathbf{N = 4}$ & $\mathbf{N = 5}$ & $\mathbf{N = 6}$ & $\mathbf{R}^{\mathbf{2}}>\mathbf{0 . 9 5}$ & $\mathbf{R}^{\mathbf{2}}>\mathbf{0 . 9 9}$ \\
\hline Spring & 0.70 & 12.02 & 33.33 & 34.61 & 19.31 & 99.86 & 96.94 \\
Summer & 0.79 & 10.47 & 28.24 & 37.09 & 23.38 & 99.86 & 97.52 \\
Autumn & 0.48 & 7.60 & 24.58 & 37.93 & 29.39 & 99.86 & 98.89 \\
Winter & 0.92 & 10.25 & 31.03 & 35.80 & 21.97 & 99.64 & 96.46 \\
All & 0.72 & 10.09 & 29.29 & 36.36 & 23.51 & 99.81 & 97.45 \\
\hline
\end{tabular}

Note: Spring includes March, April, and May; Summer includes June, July, and August; Autumn includes September, October, and November; Winter includes December, January, and February. N indicates the numbers of the Gaussian items. For details, please refer to the methods part. 
Table A2. Comparison between monthly IASI satellite-derived ground $\mathrm{NH}_{3}$ concentrations and the NNDMN monitoring sites from 2010 to 2013.

\begin{tabular}{|c|c|c|c|c|c|}
\hline \multirow{2}{*}{ Site } & \multirow{2}{*}{ Landuse } & \multirow{2}{*}{ Long $\left({ }^{\circ} \mathrm{E}\right)$} & \multirow{2}{*}{ Lat $\left({ }^{\circ} \mathbf{N}\right)$} & \multirow{2}{*}{$n$} & \multirow{2}{*}{$\begin{array}{r}R( \pm s t d) \\
\text { This Study }\end{array}$} \\
\hline & & & & & \\
\hline BYBLK & Alpine grassland & 83.71 & 42.88 & 22 & $0.68(0.05)$ \\
\hline FK & Desert-oasis ecotone & 87.93 & 44.29 & 32 & $0.49(0.04)$ \\
\hline TLF & Desert in an oasis & 89.19 & 42.85 & 28 & $0.84(0.07)$ \\
\hline SDS & Urban & 87.56 & 43.85 & 38 & $0.69(0.06)$ \\
\hline TFS & Suburban & 87.47 & 43.94 & 35 & $0.56(0.05)$ \\
\hline $\mathrm{CL}$ & Desert-oasis ecotone & 80.73 & 37.02 & 12 & $0.94(0.08)$ \\
\hline $\mathrm{TZ}$ & Desert & 83.66 & 38.97 & 12 & $0.89(0.07)$ \\
\hline YPH & Farmland & 77.27 & 39 & 12 & $0.83(0.05)$ \\
\hline $\mathrm{HT}$ & Farmland & 79.89 & 37.15 & 5 & $0.99(0.08)$ \\
\hline AKS & Farmland & 80.83 & 40.62 & 17 & $0.72(0.06)$ \\
\hline KRL & Farmland & 85.86 & 41.68 & 6 & $0.94(0.08)$ \\
\hline NLT & Forest & 84.03 & 43.31 & 4 & $0.33(0.03)$ \\
\hline NSXC & Forest & 87.04 & 43.35 & 7 & $0.98(0.09)$ \\
\hline CAU & Urban & 116.28 & 40.02 & 45 & $0.57(0.05)$ \\
\hline ZZ & Urban & 113.63 & 34.75 & 44 & $0.55(0.04)$ \\
\hline SZ & Farmland & 116.2 & 40.11 & 45 & $0.86(0.07)$ \\
\hline $\mathrm{BD}$ & Farmland & 115.48 & 38.85 & 12 & $0.44(0.04)$ \\
\hline QZ & Farmland & 114.94 & 36.78 & 45 & $0.50(0.04)$ \\
\hline$\widehat{Y Q}$ & Farmland & 112.89 & 38.05 & 45 & $0.57(0.05)$ \\
\hline ZMD & Farmland & 114.05 & 33.02 & 45 & $0.27(0.02)$ \\
\hline YL & Farmland & 108.01 & 34.31 & 45 & $0.27(0.02)$ \\
\hline YC & Farmland & 116.63 & 36.94 & 35 & $0.77(0.06)$ \\
\hline GZL & Farmland & 124.83 & 43.53 & 42 & $0.82(0.06)$ \\
\hline LS & Farmland & 124.17 & 43.36 & 42 & $0.62(0.05)$ \\
\hline DL & Coastal & 121.58 & 38.92 & 40 & $0.73(0.05)$ \\
\hline WY & Forest & 129.25 & 48.11 & 12 & $0.31(0.02)$ \\
\hline $\mathrm{GH}$ & Forest & 121.52 & 50.78 & 12 & $0.38(0.03)$ \\
\hline WW & Farmland & 102.6 & 38.07 & 39 & $0.32(0.02)$ \\
\hline DL & Grassland & 116.49 & 42.2 & 6 & $0.52(0.04)$ \\
\hline$W X$ & Farmland & 115.79 & 30.01 & 29 & $0.56(0.05)$ \\
\hline BY & Farmland & 113.27 & 23.16 & 44 & $0.47(0.04)$ \\
\hline $\mathrm{TJ}$ & Farmland & 111.97 & 28.61 & 39 & $0.42(0.03)$ \\
\hline FYU & Farmland & 113.34 & 28.56 & 40 & $0.76(0.06)$ \\
\hline $\mathrm{HN}$ & Farmland & 113.41 & 28.52 & 40 & $0.36(0.03)$ \\
\hline $\mathrm{NJ}$ & Farmland & 118.85 & 31.84 & 18 & $0.82(0.06)$ \\
\hline FY & Farmland & 117.56 & 32.88 & 11 & $0.79(0.06)$ \\
\hline $\mathrm{ZJ}$ & Coastal & 110.33 & 21.26 & 41 & $0.63(0.05)$ \\
\hline $\mathrm{FZ}$ & Coastal & 119.36 & 26.17 & 45 & $0.49(0.03)$ \\
\hline $\mathrm{FH}$ & Coastal & 121.53 & 29.61 & 41 & $0.57(0.04)$ \\
\hline $\mathrm{XS}$ & Forest & 113.31 & 28.61 & 40 & $0.67(0.06)$ \\
\hline WJ & Farmland & 103.84 & 30.55 & 39 & $0.28(0.02)$ \\
\hline $\mathrm{ZY}$ & Farmland & 104.63 & 30.13 & 42 & $0.74(0.06)$ \\
\hline $\mathrm{YT}$ & Farmland & 105.47 & 31.28 & 30 & $0.78(0.06)$ \\
\hline $\mathrm{JJ}$ & Farmland & 106.18 & 29.06 & 12 & $0.94(0.08)$ \\
\hline
\end{tabular}

\section{References}

1. Van Damme, M.; Clarisse, L.; Dammers, E.; Liu, X.; Nowak, J.; Clerbaux, C.; Flechard, C.; Galy-Lacaux, C.; $\mathrm{Xu}, \mathrm{W}$; Neuman, J.; et al. Towards validation of ammonia $\left(\mathrm{NH}_{3}\right)$ measurements from the IASI satellite. Atmos. Meas. Tech. 2014, 7, 12125-12172. [CrossRef]

2. Warner, J.; Wei, Z.; Strow, L.; Dickerson, R.; Nowak, J. The global tropospheric ammonia distribution as seen in the 13 year AIRS measurement record. Atmos. Chem. Phys. Discuss. 2015, 15, 35823-35856. [CrossRef] 
3. Van Damme, M.; Wichink Kruit, R.; Schaap, M.; Clarisse, L.; Clerbaux, C.; Coheur, P.F.; Dammers, E.; Dolman, A.; Erisman, J. Evaluating 4 years of atmospheric ammonia $\left(\mathrm{NH}_{3}\right)$ over Europe using IASI satellite observations and LOTOS-EUROS model results. J. Geophys. Res. Atmos. 2014, 119, 9549-9566. [CrossRef]

4. Paulot, F.; Jacob, D.J.; Pinder, R.; Bash, J.; Travis, K.; Henze, D. Ammonia emissions in the United States, European Union, and China derived by high-resolution inversion of ammonium wet deposition data: Interpretation with a new agricultural emissions inventory (MASAGE_NH 3 ). J. Geophys. Res. Atmos. 2014, 119, 4343-4364. [CrossRef]

5. Kruit, R.J.W.; Schaap, M.; Sauter, F.J.; Zanten, M.C.V. Modeling the distribution of ammonia across Europe including bi-directional surface-atmosphere exchange. Biogeosciences 2012, 9, 5261-5277. [CrossRef]

6. Sutton, M.A.; Reis, S.; Riddick, S.N.; Dragosits, U.; Nemitz, E.; Theobald, M.R.; Tang, Y.S.; Braban, C.F.; Vieno, M.; Dore, A.J.; et al. Towards a climate-dependent paradigm of ammonia emission and deposition. Philos. Trans. R. Soc. B Biol. Sci. 2013, 368. [CrossRef] [PubMed]

7. Gu, B.; Sutton, M.A.; Chang, S.X.; Ge, Y.; Chang, J. Agricultural ammonia emissions contribute to China's urban air pollution. Front. Ecol. Environ. 2014, 12, 265-266. [CrossRef]

8. Gu, B.; Ge, Y.; Ren, Y.; Xu, B.; Luo, W.; Jiang, H.; Gu, B.; Chang, J. Atmospheric reactive nitrogen in China: Sources, recent trends, and damage costs. Environ. Sci. Technol. 2012, 46, 9420-9427. [CrossRef] [PubMed]

9. Pope, C.A., III; Burnett, R.T.; Thun, M.J.; Calle, E.E.; Krewski, D.; Ito, K.; Thurston, G.D. Lung cancer, cardiopulmonary mortality, and long-term exposure to fine particulate air pollution. JAMA 2002, 287, 1132-1141. [CrossRef] [PubMed]

10. Zhou, Y.; Shuiyuan, C.; Lang, J.; Chen, D.; Zhao, B.; Liu, C.; Xu, R.; Li, T. A comprehensive ammonia emission inventory with high-resolution and its evaluation in the Beijing-Tianjin-Hebei (BTH) region, China. Atmos. Environ. 2015, 106, 305-317. [CrossRef]

11. Luo, M.; Shephard, M.W.; Cady-Pereira, K.E.; Henze, D.K.; Zhu, L.; Bash, J.O.; Pinder, R.W.; Capps, S.L.; Walker, J.T.; Jones, M.R. Satellite observations of tropospheric ammonia and carbon monoxide: Global distributions, regional correlations and comparisons to model simulations. Atmos. Environ. 2015, 106, 262-277. [CrossRef]

12. Hamaoui-Laguel, L.; Meleux, F.; Beekmann, M.; Bessagnet, B.; Génermont, S.; Cellier, P.; Létinois, L. Improving ammonia emissions in air quality modelling for France. Atmos. Environ. 2014, 92, 584-595. [CrossRef]

13. Wen, D.; Zhang, L.; Lin, J.; Vet, R.; Moran, M. An evaluation of ambient ammonia concentrations over southern Ontario simulated with different dry deposition schemes within STILT-Chem v0.8. Geosci. Model Dev. 2014, 7, 1037-1050. [CrossRef]

14. Wen, D.; Lin, J.; Zhang, L.; Vet, R.; Moran, M. Modeling atmospheric ammonia and ammonium using a stochastic Lagrangian air quality model (STILT-Chem v0.7). Geosci. Model Dev. 2013, 6, 327-344. [CrossRef]

15. Van Donkelaar, A.; Martin, R.V.; Park, R.J. Estimating ground-level PM2.5 using aerosol optical depth determined from satellite remote sensing. J. Geophys. Res. Atmos. 2006, 111. [CrossRef]

16. Liu, Y.; Park, R.J.; Jacob, D.J.; Li, Q.; Kilaru, V.; Sarnat, J.A. Mapping annual mean groun-level PM2.5 concentrations using Multiangle Imaging Spectroradiometer aerosol optical thickness over the contiguous United States. J. Geophys. Res. Atmos. 2004, 109, 1-10.

17. Van Donkelaar, A.; Martin, R.V.; Brauer, M.; Kahn, R.; Levy, R.; Verduzco, C.; Villeneuve, P.J. Global estimates of ambient fine particulate matter concentrations from satellite-based aerosol optical depth: Development and application. Environ. Health Perspect. 2010, 118, 847. [CrossRef] [PubMed]

18. Wang, J.; Xu, X.; Spurr, R.; Wang, Y.; Drury, E. Improved algorithm for MODIS satellite retrievals of aerosol optical thickness over land in dusty atmosphere: Implications for air quality monitoring in China. Remote Sens. Environ. 2010, 114, 2575-2583. [CrossRef]

19. Nowlan, C.; Martin, R.; Philip, S.; Lamsal, L.; Krotkov, N.; Marais, E.; Wang, S.; Zhang, Q. Global dry deposition of nitrogen dioxide and sulfur dioxide inferred from space-based measurements. Glob. Biogeochem. Cycles 2014, 28, 1025-1043. [CrossRef]

20. Lamsal, L.N.; Martin, R.V.; van Donkelaar, A.; Steinbacher, M.; Celarier, E.A.; Bucsela, E.; Dunlea, E.J.; Pinto, J.P. Ground-level nitrogen dioxide concentrations inferred from the satellite-borne Ozone Monitoring Instrument. J. Geophys. Res. Atmos. 2008, 113, 1-15. [CrossRef] 
21. Hudman, R.C.; Jacob, D.J.; Turquety, S.; Leibensperger, E.M.; Murray, L.T.; Wu, S.; Gilliland, A.B.; Avery, M.; Bertram, T.H.; Brune, W.; et al. Surface and lightning sources of nitrogen oxides over the United States: Magnitudes, chemical evolution, and outflow. J. Geophys. Res. Atmos. 2007, 112, 1-14. [CrossRef]

22. Dammers, E.; Vigouroux, C.; Palm, M.; Mahieu, E.; Warneke, T.; Smale, D.; Langerock, B.; Franco, B.; Damme, M.V.; Schaap, M.; et al. Retrieval of ammonia from ground-based FTIR solar spectra. Atmos. Chem. Phys. 2015, 15, 12789-12803. [CrossRef]

23. Van Damme, M.; Erisman, J.W.; Clarisse, L.; Dammers, E.; Whitburn, S.; Clerbaux, C.; Dolman, A.J.; Coheur, P.F. Worldwide spatiotemporal atmospheric ammonia $\left(\mathrm{NH}_{3}\right)$ columns variability revealed by satellite. Geophys. Res. Lett. 2015, 42, 8660-8668. [CrossRef]

24. Emmons, L.; Walters, S.; Hess, P.; Lamarque, J.-F.; Pfister, G.; Fillmore, D.; Granier, C.; Guenther, A.; Kinnison, D.; Laepple, T.; et al. Description and evaluation of the Model for Ozone and Related chemical Tracers, version 4 (MOZART-4). Geosci. Model Dev. 2010, 3, 43-67. [CrossRef]

25. Lee, C.; Martin, R.V.; van Donkelaar, A.; Lee, H.; Dickerson, R.R.; Hains, J.C.; Krotkov, N.; Richter, A.; Vinnikov, K.; Schwab, J.J. $\mathrm{SO}_{2}$ emissions and lifetimes: Estimates from inverse modeling using in situ and global, space-based (SCIAMACHY and OMI) observations. J. Geophys. Res. Atmos. 2011, 116, 1-13. [CrossRef]

26. Coheur, P.-F.; Clarisse, L.; Turquety, S.; Hurtmans, D.; Clerbaux, C. IASI measurements of reactive trace species in biomass burning plumes. Atmos. Chem. Phys. 2009, 9, 5655-5667. [CrossRef]

27. Liu, L.; Zhang, X.; Xu, W.; Liu, X.; Li, Y.; Lu, X.; Zhang, Y.; Zhang, W. Temporal characteristics of atmospheric ammonia and nitrogen dioxide over China based on emission data, satellite observations and atmospheric transport modeling since 1980. Atmos. Chem. Phys. Discuss. 2017, 2017, 1-32. [CrossRef]

28. Hertel, O.; Skjøth, C.A.; Reis, S.; Bleeker, A.; Harrison, R.; Cape, J.N.; Fowler, D.; Skiba, U.; Simpson, D.; Jickells, T.; et al. Governing processes for reactive nitrogen compounds in the European atmosphere. Biogeosciences 2012, 9, 4921-4954. [CrossRef]

29. Liu, X.; Duan, L.; Mo, J.; Du, E.; Shen, J.; Lu, X.; Zhang, Y.; Zhou, X.; He, C.; Zhang, F. Nitrogen deposition and its ecological impact in China: An overview. Environ. Pollut. 2011, 159, 2251-2264. [CrossRef] [PubMed]

30. Xu, W.; Luo, X.S.; Pan, Y.P.; Zhang, L.; Tang, A.H.; Shen, J.L.; Zhang, Y.; Li, K.H.; Wu, Q.H.; Yang, D.W.; et al. Quantifying atmospheric nitrogen deposition through a nationwide monitoring network across China. Atmos. Chem. Phys. 2015, 15, 12345-12360. [CrossRef]

31. Flechard, C.R.; Nemitz, E.; Smith, R.I.; Fowler, D.; Vermeulen, A.T.; Bleeker, A.; Erisman, J.W.; Simpson, D.; Zhang, L.; Tang, Y.S.; et al. Dry deposition of reactive nitrogen to European ecosystems: A comparison of inferential models across the NitroEurope network. Atmos. Chem. Phys. 2011, 2011, 2703-2728. [CrossRef]

32. Whitburn, S.; Van Damme, M.; Clarisse, L.; Bauduin, S.; Heald, C.L.; Hadji-Lazaro, J.; Hurtmans, D.; Zondlo, M.A.; Clerbaux, C.; Coheur, P.F. A flexible and robust neural network IASI-NH $\mathrm{N}_{3}$ retrieval algorithm. J. Geophys. Res. Atmos. 2016, 121, 6581-6599. [CrossRef]

33. Sahu, L.; Sheel, V.; Kajino, M.; Gunthe, S.S.; Thouret, V.; Nedelec, P.; Smit, H.G. Characteristics of tropospheric ozone variability over an urban site in Southeast Asia: A study based on MOZAIC and MOZART vertical profiles. J. Geophys. Res. Atmos. 2013, 118, 8729-8747. [CrossRef]

34. Xu, P.; Liao, Y.J.; Lin, Y.H.; Zhao, C.X.; Yan, C.H.; Cao, M.N.; Wang, G.S.; Luan, S.J. High-resolution inventory of ammonia emissions from agricultural fertilizer in China from 1978 to 2008. Atmos. Chem. Phys. 2016, 16, 1207-1218. [CrossRef]

35. Huang, X.; Song, Y.; Li, M.; Li, J.; Huo, Q.; Cai, X.; Zhu, T.; Hu, M.; Zhang, H. A high resolution ammonia emission inventory in China. Glob. Biogeochem. Cycles 2012, 26, 1-14. [CrossRef]

36. Kang, Y.; Liu, M.; Song, Y.; Huang, X.; Yao, H.; Cai, X.; Zhang, H.; Kang, L.; Liu, X.; Yan, X.; et al. High-resolution ammonia emissions inventories in China from 1980 to 2012. Atmos. Chem. Phys. 2016, 16, 2043-2058. [CrossRef]

37. Xu, P.; Zhang, Y.; Gong, W.; Hou, X.; Kroeze, C.; Gao, W.; Luan, S. An inventory of the emission of ammonia from agricultural fertilizer application in China for 2010 and its high-resolution spatial distribution. Atmos. Environ. 2015, 115, 141-148. [CrossRef]

38. Zhang, Y.; Dore, A.; Ma, L.; Liu, X.; Ma, W.; Cape, J.; Zhang, F. Agricultural ammonia emissions inventory and spatial distribution in the North China Plain. Environ. Pollut. 2010, 158, 490-501. [CrossRef] [PubMed]

39. Aneja, V.P.; Chauhan, J.; Walker, J. Characterization of atmospheric ammonia emissions from swine waste storage and treatment lagoons. J. Geophys. Res. Atmos. 2000, 105, 11535-11545. [CrossRef] 
40. Pan, Y.; Wang, Y.; Tang, G.; Wu, D. Spatial distribution and temporal variations of atmospheric sulfur deposition in Northern China: Insights into the potential acidification risks. Atmos. Chem. Phys. 2013, 13, 1675-1688. [CrossRef]

41. Fuente, A.D.L.; Bing, N.; Hoeschele, I.; Mendes, P. Discovery of meaningful associations in genomic data using partial correlation coefficients. Bioinformatics 2004, 20, 3565. [CrossRef] [PubMed]

42. Sommer, S.G.; Olesen, J.E.; Christensen, B.T. Effects of temperature, wind speed and air humidity on ammonia volatilization from surface applied cattle slurry. J. Agric. Sci. 1991, 117, 91-100. [CrossRef]

43. Cassity-Duffey, K.; Cabrera, M.; Rema, J. Ammonia Volatilization from Broiler Litter: Effect of Soil Water Content and Humidity. Soil Sci. Soc. Am. J. 2015, 79, 543-550. [CrossRef]

44. Vet, R.; Artz, R.S.; Carou, S.; Shaw, M.; Ro, C.-U.; Aas, W.; Baker, A.; Bowersox, V.C.; Dentener, F.; Galy-Lacaux, C.; et al. A global assessment of precipitation chemistry and deposition of sulfur, nitrogen, sea salt, base cations, organic acids, acidity and $\mathrm{pH}$, and phosphorus. Atmos. Environ. 2014, 93, 3-100. [CrossRef]

45. Zhao, Y.; Zhang, L.; Chen, Y.; Liu, X.; Xu, W.; Pan, Y.; Duan, L. Atmospheric nitrogen deposition to China: A model analysis on nitrogen budget and critical load exceedance. Atmos. Environ. 2017, 153, 32-40. [CrossRef]

46. Dong, W.X.; Xing, J.; Wang, S.X. Temporal and spatial distribution of anthropogenic ammonia emissions in China: 1994-2006. Huanjing Kexue Environ. Sci. 2010, 31, 1457-1463.

47. Zhang, L.; Jacob, D.J.; Knipping, E.M.; Kumar, N.; Munger, J.W.; Carouge, C.; Van Donkelaar, A.; Wang, Y.; Chen, D. Nitrogen deposition to the United States: Distribution, sources, and processes. Atmos. Chem. Phys. 2012, 12, 4539-4554. [CrossRef]

(c) 2017 by the authors. Licensee MDPI, Basel, Switzerland. This article is an open access article distributed under the terms and conditions of the Creative Commons Attribution (CC BY) license (http://creativecommons.org/licenses/by/4.0/). 